Author version: Cont. Shelf Res., vol.30 (9); 2010; 1070-1084

\title{
Seasonal variations and trophic ecology of microzooplankton in the southeastern Arabian Sea
}

\author{
C. R. Asha Devi ${ }^{1}$, R. Jyothibabu ${ }^{1}$, , P. Sabu ${ }^{1}$, Josia Jacob ${ }^{1}$, H. Habeebrehman ${ }^{1}$, \\ M. P. Prabhakaran ${ }^{1}$, K. J. Jayalakshmi ${ }^{1}$, C. T. Achuthankutty ${ }^{1}$ \\ ${ }^{1}$ National Institute of Oceanography, Regional Centre, Kochi - 682018, India
}

\begin{abstract}
The seasonal ecological response of microzooplankton in the southeastern Arabian Sea is presented. During the spring intermonsoon period (March), stratification and depletion of nitrate in the surface waters (nitracline was at $60 \mathrm{~m}$ depth) caused low integrated chlorophyll $a$ (av. $19 \pm 11.3 \mathrm{mg} \mathrm{m}^{-2}$ ) and primary production (av. $164 \pm 91 \mathrm{mgC} \mathrm{m}^{-2} \mathrm{~d}^{-1}$ ). On the other hand, nutrient enrichment associated with coastal upwelling and river influx during the onset and peak summer monsoon resulted in high integrated chlorophyll $a$ (av. $21 \pm 6 \mathrm{mg} \mathrm{m}^{-2}$ and av. $29 \pm 21 \mathrm{mg} \mathrm{m}^{-3}$ respectively) and primary production (av. $255 \pm 94 \mathrm{mg} \mathrm{Cm}^{-2} \mathrm{~d}^{-1}$ and av. $335 \pm 278 \mathrm{mgC} \mathrm{m}^{-2} \mathrm{~d}^{-1}$ respectively). During all three periods, diazotropic cyanobacterium Trichodesmium erythraeum dominated in the nutrient depleted surface waters. A general increase in abundance of larger diatoms was evident in the surface waters of the inshore region during monsoon periods. The microzooplankton abundance was found to be significantly higher during the spring intermonsoon (av.241 $\pm 113 \times 10^{3}$ ind. $\mathrm{m}^{-2}$ ) as compared to onset of summer monsoon (av. $105 \pm 89 \times 10^{3}$ ind. $\mathrm{m}^{-2}$ ) and peak summer monsoon (av.185 $\pm 175 \times 10^{3}$ ind.m ${ }^{-2}$ ). Microzooplankton community during the spring intermonsoon was numerically dominated by ciliates while heterotrophic dinoflagellate was the dominant ones during the monsoon periods. The high abundance of ciliates during the spring intermonsoon could be attributed to the stratified environmental condition prevailed in the study area which favors high abundance of smaller phytoplankton and cyanobacteria, the most preferred food of ciliates. On the other hand, the dominance of heterotrophic dinoflagellates during the monsoon periods could be linked to their ability to graze larger diatoms which were abundant during the monsoon periods. The overall results show low abundance of microzooplankton in the eastern Arabian Sea during the monsoon periods mainly due to a decline in ciliates abundance. This decline during the monsoon periods could be the result of (a) low abundance of smaller phytoplankton and (b) high stock of mesozooplankton predators (av. $245 \mathrm{ml} 100 \mathrm{~m}^{-3}$ ).
\end{abstract}

Key Words: Microzooplankton, dinoflagellates, ciliates, stratification, upwelling, Southeastern Arabian Sea *Corresponding author. E mail: rjyothibabu@nio.org 


\section{Introduction}

The microzooplankton (MZP), heterotrophic plankton with body size 20-200 $\mu \mathrm{m}$, plays an important role in marine pelagic ecosystems in transferring primary organic carbon to higher trophic levels (Dussart, 1963; Godhantaraman et al., 2004). They are mostly comprised of ciliates, heterotrophic dinoflagellates and crustacean nauplii, capable of exploiting pico and nanoplankton that are inefficiently utilized by other larger zooplankton (Marshall, 1973; Nival and Nival, 1976). MZP also acts as a significant food source for a variety of zooplankton and vertebrate predators (Robertson 1983, Stoecker and Capuzzo 1990; Fukami et al., 1999), thereby acting as a trophic intermediate between pico/nano plankton and mesozooplankton.

Studies have also shown that MZP dominates among grazers of tropical oceanic phytoplankton in the Pacific Ocean (Miller, 1993), Atlantic Ocean (Burkill et al., 1993 a, Verity et al., 1993) and Indian Ocean (Burkill et al., 1993 b). The high growth rates of MZP enable them to respond rapidly to changes in phytoplankton communities, resulting in a close coupling between primary producers and grazers within the food-web (Verity et al. 1993; Landry et al., 1995). MZP are also known to be a critical link that transfers organic carbon from heterotrophic bacteria to higher trophic levels through the microbial loop (Azam et al., 1983). In the Arabian Sea, the microbial loop seems to play a significant role in maintaining high mesozooplankton biomass throughout the year (Madhupratap et al., 1996).

In spite of the crucial ecological importance of MZP in marine pelagic food webs, information on their diversity, abundance and biomass from the eastern Arabian Sea are lacking. The limited information available highlights their important functional role in the eastern Arabian Sea in mediating transfer of phytoplankton and bacterial carbon to higher trophic level (Gauns et al., 1996). On this backdrop, we studied the MZP community of the eastern Arabian Sea with respect to the environmental changes during the spring intermonsoon (SIM), onset of the summer monsoon (OSM) and peak summer monsoon (PSM) with the following objectives (a) to generate baseline information on their composition, abundance, diversity and ecology; (b) to characterize them with respect to the environmental changes from SIM to PSM periods and (c) to understand their relationship with the mesozooplankton community.

\section{Materials and methods}

\subsection{Study Area}

The area of investigation was the southeastern Arabian Sea $\left(8-15^{\circ} \mathrm{N}\right.$ and $\left.69-77^{\circ} \mathrm{E}\right)$, bordered by the Indian subcontinent on the eastern side (Figure 1). This region has unique oceanographic 
features mainly with respect to the monsoonal winds, which drive near - surface currents and affect mixed layer development, hence nutrient availability in the upper euphotic zone. Based on the diverse oceanographic features of the study area, seasons are mainly classified into spring intermonsoon (March to May), summer monsoon (June to September) and winter monsoon (November to February).

The SIM is a transition period from winter to summer monsoons. During this period, the eastern Arabian Sea is exposed to intense solar heating (summer) and characterized by weak winds, making the surface layer of the ocean stratified (Muraleedharan and Prasannakumar, 1996). In addition, the low saline oligotrophic Bay of Bengal water that occupies the surface layers of the southeastern Arabian Sea (Figure 2) intensifies the stratification during SIM period (Sanilkumar et al., 2003). Besides, the small amount of rainfall on the Indian subcontinent during the period causes a reduction in the volume of nutrient rich river influx closer to the coast (Qasim, 2003). The combined effect of these processes cause depletion of nutrients in the upper euphotic zone (upper $60 \mathrm{~m}$ of the water column has near zero concentrations of nitrate). This eventually leads to low primary production and phytoplankton abundance in the southeastern Arabian Sea during the SIM (Bhattathiri et al., 1996).

With the OSM, nutrient concentrations in the inshore surface waters increase due to coastal upwelling resulting in enhanced biological production (Madhupratap et al., 1990; Nair et al., 1992). The onset of upwelling occurs at the southern part of the west coast of India by the end of May - early June, propagating northwards with time (Madhupratap et al., 2001). Apart from upwelling, nutrient rich river runoff also stimulates biological production along the southwest coast of India (Madhupratap et al., 2001; Nair et al., 1992). The resulting high nutrient content in the surface waters induces proliferation of diatoms (Madhupratap, 1990; Nair et al., 1992; Sawant and Madhupratap., 1996).

During the PSM, wind along the southwest coast of India attains its peak velocity intensifying the coastal upwelling (Shankar et al., 2002a). As a result, the vertical advection of nutrient-rich subsurface waters also increases resulting in high availability of macronutrients in the surface. In addition to this, increased nutrient-rich freshwater influx from the westward flowing Indian rivers maintains high level of macronutrient availability in the waters closer to the coast. The combined effect of both processes creates a nutrient-rich environment along the southwest coast of India during the PSM which supports the highest annual phytoplankton stock and production (Madhupratap, 1990, Banse et al., 1996).

\subsection{Methods}

Seasonal samplings were carried out onboard FORV Sagar Sampada during the SIM (19 March- 7 April, 2004), OSM (27 May - 13 June, 2005) and PSM (25 August- 11 September, 2005). 
The sampling locations were selected in five transects along 8, 10, 11.5, 13 and $15^{\circ} \mathrm{N}$ (Fig. 1). On each transect, water samples for measuring biological parameters such as phytoplankton, chlorophyll $a$, primary production and MZP were collected from two locations, one near to the coast (inshore) and one in the oceanic region (offshore). The inshore locations were selected in such a way that the depth was sufficient to operate an in situ primary productivity mooring system ( 200m depth).

\subsubsection{Physico - chemical parameters}

Winds were monitored by an automated weather station onboard the ship and the data was retrieved using Integrated Data Acquisition Software. The vertical profiles of temperature and salinity of all study locations were recorded using a Conductivity Temperature Depth profiler (CTD - Seabird Electronics Sea sat, SBE 911 Plus, USA). The Mixed Layer Depth (MLD) was taken as the depth at which $1^{\circ} \mathrm{C}$ drop of Sea Surface Temperature (SST) was observed (Prasannakumar et al., 1996). Niskin bottles mounted on a CTD rosette were used to collect water samples from 8 discrete standard depths $(0.5,10,20,30,50,75,100$ and $120 \mathrm{~m})$ for measuring dissolved oxygen (DO) and macronutrients (nitrate, phosphate and silicate). DO was estimated following Winkler's titration method. The concentration of nitrate and silicate was analyzed by an autoanalyser (SKALAR, Model 51001-1) following the principles of Grasshoff et al., (1983). Phosphate concentration was measured spectrophotometrically following standard method (Grasshoff et al., 1983).

\subsubsection{Chlorophyll $a$, phytoplankton and primary production}

Two litre of water sample were collected from 7 standard depths $(0.5,10,20,50,75,100$ and $120 \mathrm{~m}$ ) from the Niskin bottles for the estimation of chlorophyll $a$ and phytoplankton. One litre of sample from each depth was passed through GF/F filter paper and the chlorophyll $a$ was extracted in 90\% acetone and measured spectrophotometrically (Strickland and Parsons, 1972). Column (integrated) values of chlorophyll $a$ was calculated by integrating the discrete depth values (from surface to $120 \mathrm{~m}$ ).

For phytoplankton analysis, $500 \mathrm{ml}$ of water sample was preserved in Lugol's iodine. The analysis of phytoplankton samples include initial concentration of water samples to $10 \mathrm{ml}$ volume based on settling and siphoning procedure. Subsequently 5 - 7 sub-samples of $1 \mathrm{ml}$ in a Sedgwick rafter counting chamber were analysed under an inverted microscope at 100 - 400x magnification following the standard literature (Subrahmanyan, 1959, 1971; Tomas, 1997).

Water samples (2 litre) for measuring primary productivity were collected from seven standard depths (same as that of chlorophyll) before dawn ( 0500 hours). Samples were carefully transferred to clean Nalgene polycarbonate bottles and ${ }^{14} \mathrm{C}$ - incubation was carried out in situ following UNESCO, 
(1994). Column (integrated) values of primary production was calculated by integrating the discrete depth values (from surface to $120 \mathrm{~m}$ ).

\subsubsection{Microzooplankton (MZP)}

Water samples (5 - 8 liter) for MZP were collected from the same depths as those of chlorophyll $a$ and primary production (0.5, 10, 20, 50, 75, 100 ad $120 \mathrm{~m}$ ). Samples were prefiltered through a $200 \mu \mathrm{m}$ bolting silk to eliminate the mesozooplankton and the filtrate was carefully collected in black polythene bottles. Although the screening of samples through $200 \mu \mathrm{m}$ sieve may disturb large and fragile MZP, this process is widely used in MZP sampling for discarding the mesozooplankton (Froneman and McQuaid 1997; Putland, 2000; Stelfox - Widdicombe et al., 2004). Subsequently, 3 $8 \%$ of acid Lugol's iodine was added to the sieved samples. These samples were then concentrated by gravity settling and siphoning procedure. Thus the samples were concentrated to $100 \mathrm{ml}$ and preserved in 1 - 3\% acid Lugol's solution. Although there are some conflicts of opinion on the suitability of various fixatives for MZP, the acid Lugol's iodine is considered as the most useful and widely adopted one, since it causes lesser damage to various groups of MZP community than other preservatives (Gifford and Caron., 2000). However, there could be some underestimation of heterotrophic dinoflagellates in the present study due to cell loss resulting from fixation in acid Lugols iodine. Prior to the microscopic analysis, the initial $100 \mathrm{ml}$ sample was allowed to settle for 2 days and concentrated to $20 \mathrm{ml}$ final concentration. Several sub-samples (5-8) of $1 \mathrm{ml}$ each were analyzed in Sedgwick rafter counting chamber under an inverted microscope with phase contrast optics (100 - 400x) magnifications. The organisms present in the samples were identified and categorized into four groups viz., heterotrophic dinoflagellates, ciliates, sarcordines and crustacean nauplii. The heterotrophic forms of dinoflagellates were differentiated from autotrophs following Steidinger and Williams, 1970; Subrahmanyan, 1971; Taylor, 1976a and b; 1987. Similarly, ciliates were identified to the species level wherever possible and the sarcordines and crustacean nauplii were categorized to the group level (Kofoid and Campbell., 1939; Jorgenson, 1924; Marshall, 1969; Corliss, 1979; Maeda and Carey, 1985; Maeda, 1986; Lynn et al., 1988). The abundance of MZP at the sampled depths was integrated to calculate the water column (integrated) values.

\subsubsection{Mesozooplankton}

A Multiple Plankton Net (Hydro - Bios, mouth area $0.25 \mathrm{~m}^{2}$, mesh width $200 \mu \mathrm{m}$ ) with an electronic depth sensor was operated vertically to collect mesozooplankton samples. Samples were collected from the bottom of thermocline to the surface to get a fair representation of the euphotic column. The zooplankton collections were carried out around the noon to avoid the possible error on biomass due to vertical migration. Mesozooplankton biomass was measured as displacement volume.

\subsubsection{Diversity}


Diversity is a concise expression of how individuals of a community are distributed in subsets of groups. The following diversity indices have been used to analyze changes in plankton community due to environmental influence (a) Species richness - the number of different species in a particular area (Margalef, 1968) (b) Species evenness - the relative abundance with which each species are represented in an area (Heips, 1974) and (c) Species diversity - this index takes into account the number of species and the evenness of the species. The index is increased either by having more unique species, or by having greater species evenness (Shannon and Weaver, 1963).

\subsubsection{Multi-Dimensional Scaling and Hierarchical Clustering}

These multivariate analyses have been carried out to see the seasonal species similarity/difference at different locations using Plymouth Routine in Marine Environmental Research (PRIMER - Clarke and Gorley, 2001). The similarity/differences in species abundance can directly be related to the prevailing environmental conditions. MDS attempts to arrange "objects" (in the present case MZP species abundance at different locations) in a space so as to reproduce the observed similarities. As a result, we can explain the distances in terms of dissimilarity between species occurring in different depths.

\section{Results}

\subsection{Physicochemical features}

\subsubsection{SIM}

The period was characterized by clear sky, high solar radiation and weak northerly winds (av. $4.2 \mathrm{~m} \mathrm{~s}^{-1}$ ). SST distribution showed a spatial variation between 29.4 and $30.3^{\circ} \mathrm{C}$ with a warming trend towards the coast (Fig. 2a). A thin layer of low saline surface waters $(<34.2)$ was found in the inshore region between 8 and $15^{\circ} \mathrm{N}$ (Fig. 2b). Relatively high SST (>30 ${ }^{\circ} \mathrm{C}$ ) and shallow MLD were present in the inshore region (Fig. 2a \& c). The vertical distribution of temperature and salinity showed warm and low saline waters along the inshore region (Fig. 3a \& b). Weak winds, low salinity and high SST favoured surface layer stratification in a major part of the study area (MLD av. $35 \mathrm{~m}$ ) (Fig. 2c). Stratification favored enriched levels of DO $(>200 \mu \mathrm{M})$ in the upper $40-60 \mathrm{~m}$ of the euphotic column (Fig. 3c), which is typical of the Indian seas during the SIM period. Stratification also caused a general lack of macronutrients in the upper euphotic column (Fig. 3d, e \& f). The nitracline (1 $\mu \mathrm{M}$ concentration of nitrate) was found in 60 - $80 \mathrm{~m}$ depth; upper $60 \mathrm{~m}$ water column had $<0.8 \mu \mathrm{M}$ of phosphate and $<3 \mu \mathrm{M}$ of silicate (Fig. 3d, e \& f).

\subsubsection{OSM}


Strong southwesterly wind (av. $7 \mathrm{~m} \mathrm{~s}^{-1}$ ) was prevalent during the period. SST varied between 30.2 and $31.2^{\circ} \mathrm{C}$ with warmer waters in the offshore region (Fig. 2a). The distribution of isohalines showed high salinity waters (>35.4) in the north (Fig. 2b) and shallow MLD in the inshore region of the southern transects (Fig. 2c). Vertical sections of temperature distribution along the inshore region showed shoaling up of isotherms between 8 and $11^{\circ} \mathrm{N}$ (Fig. 4a). A low saline plume was also found in the surface waters between 8 and $12^{\circ} \mathrm{N}$ (Fig. 4b). The DO concentration in the surface waters of the inshore region was less compared to the offshore (Fig. 4c). The decrease in DO was clearer in the south of $10^{\circ} \mathrm{N}$ where $190 \mu \mathrm{M}$ contour was found at $20 \mathrm{~m}$ depth (Fig. 4c). Concentration of all macronutrients in the surface waters of the inshore region was many folds higher compared to the offshore region (Fig. 4d, e \& f). The nutrient values in the inshore region during the OSM were much higher than the corresponding values during the SIM. On the other hand, the concentration of DO and macronutrients in the offshore region during the OSM did not show much change from that of SIM (Fig. 3c-f \& 4c-f). This indicates that the changes in hydrographical conditions from SIM to OSM were very prominent only in the inshore region whereas the changes were of low key in the offshore regions.

\subsubsection{PSM}

During the period, the wind was the strongest (av. $8 \mathrm{~m} \mathrm{~s}^{-1}$ ) and SST was the lowest (25.2 $28.3^{\circ} \mathrm{C}$ ) among the three periods studied (Fig. 2a). Marked decline in SST ( $\sim 4^{\circ} \mathrm{C}$ with respect to OSM) was found along the inshore region (Fig. 2a). Signatures of upwelling (up-sloping of isolines) were evident in the vertical structures of temperature, salinity, DO and nutrients along the inshore region (Fig. 5a-f). Warmer and high saline waters were found in the offshore region (Fig. 2a \&b). Upwelling signatures were present over the entire inshore waters $\left(8^{\circ}\right.$ to $\left.15^{\circ} \mathrm{N}\right)$ as evidenced by the presence of low oxygenated, high nutrient subsurface waters at the surface (Fig. 5c-f). Upwelling was more active in the inshore region south of $13^{\circ} \mathrm{N}$, where prominent up-sloping of isolines were evident in the vertical structures (Fig. 5c-f). The nitracline, which was usually found above $20 \mathrm{~m}$ depth all along the inshore waters, was located near-surface waters between 10 and $11.5^{\circ} \mathrm{N}$ (Fig. 5d). On the other hand, nutrient enrichment in the surface waters of the offshore region was in a low key. The upper $50 \mathrm{~m}$ water column in the offshore region had low levels of nutrients $\left(\mathrm{NO}_{3}<2 \mu \mathrm{M}, \mathrm{PO}_{4}<0.5 \mu \mathrm{M}\right.$ and $\left.\mathrm{SiO}_{4}<2 \mu \mathrm{M}\right)$.

\subsection{Chlorophyll $a$, primary production and phytoplankton}

\subsubsection{SIM}

The integrated values of chlorophyll $a$ and primary production were generally low (av. $19.5 \pm$ $11.3 \mathrm{mg} \mathrm{m}^{-2}$ and av. $164 \pm 91 \mathrm{mgC} \mathrm{m}^{-2} \mathrm{~d}^{-1}$ respectively) during the period (Table 1 ). Surface chlorophyll $a$ was higher in the inshore waters (av. $0.3 \pm 0.2 \mathrm{mg} \mathrm{m}^{-3}$ ) than the offshore (av. $0.1 \pm 0.1 \mathrm{mg} \mathrm{m}^{-3}$ ), but 
the integrated values were higher in the offshore (av. $24 \pm 13 \mathrm{mg} \mathrm{m}^{-2}$ ) than the inshore (av. $15 \pm 8 \mathrm{mg}$ $\mathrm{m}^{-2}$ ). Surface and integrated primary production were higher in the inshore waters (av. $4.7 \pm 1.9 \mathrm{mgC} \mathrm{m}^{-}$ ${ }^{3} \mathrm{~d}^{-1}$ and $154 \pm 105 \mathrm{mgC} \mathrm{m} \mathrm{d}^{-1}$ ) than the offshore (av. $2.9 \pm 1.6 \mathrm{mgC} \mathrm{m}^{-3} \mathrm{~d}^{-1}$ and $151 \pm 72 \mathrm{mgC} \mathrm{m}^{-2} \mathrm{~d}^{-1}$ ). The phytoplankton abundance at the surface was higher in the offshore region (av. $269 \pm 273 \times 10^{4}$ cells $\mathrm{m}^{-3}$ ) compared to the inshore (av. $137 \pm 825 \times 10^{4}$ cells $\mathrm{m}^{-3}$ ). The composition of surface phytoplankton community was found to be similar in both inshore and offshore regions. The dominant species in their order of mean abundance was Trichodesmium erythraeum (av. $2000 \mathrm{x} 10^{3} \mathrm{cells} \mathrm{m}^{-3}$ ) > Nitszchia pungens (av. $220 \times 10^{3}$ cells $\mathrm{m}^{-3}$ ) $>$ Rhizosolenia alata (av. $119 \times 10^{3}$ cells $\mathrm{m}^{-3}$ ) > Thalassiothrix (av. $88 \times 10^{3}$ cells $\mathrm{m}^{-3}$ ) $>$ Bacillaria (av. $81 \times 10^{3}$ cells $\mathrm{m}^{-3}$ ) $>$ Leptocylindrus $\left(\right.$ av. $80 \times 10^{3}$ cells $\mathrm{m}^{-3}$ ). The abundance of Trichodesmium erythraeum was much higher in the offshore (av. $4000 \mathrm{x}$ $10^{3}$ cells $\mathrm{m}^{-3}$ ) compared to the inshore (av. $1000 \times 10^{3}$ cells $\mathrm{m}^{-3}$ ).

\subsubsection{OSM}

There was a general increase in integrated chlorophyll $a$ and primary production (av. $21 \pm 6 \mathrm{mg}$ $\mathrm{m}^{-2}$ and av. $255 \pm 94 \mathrm{mg} \mathrm{Cm}^{-2} \mathrm{~d}^{-1}$ ) from that of the SIM (av. $19.5 \pm 11.3 \mathrm{mg} \mathrm{m}^{-2}$ and av. $164 \pm 91 \mathrm{mgC}$ $\mathrm{m}^{-2} \mathrm{~d}^{-1}$ respectively) (Table 1, Fig. 6). The surface and integrated chlorophyll $a$ in the inshore waters (av. $0.3 \pm 0.07 \mathrm{mg} \mathrm{m}^{-3}$ and av. $22 \pm 8 \mathrm{mg} \mathrm{m}^{-2}$ respectively) were found to be higher than that of the offshore (av. $0.21 \pm 0.1 \mathrm{mg} \mathrm{m}^{-3}$ and av.19 $\pm 3 \mathrm{mg} \mathrm{m}^{-2}$ respectively). The surface and integrated primary production also showed similar trend with higher values in the inshore region (av. $9 \pm 4 \mathrm{mgC} \mathrm{m}^{-3} \mathrm{~d}^{-1}$ and av. $301 \pm 103 \mathrm{mgC} \mathrm{m} \mathrm{d}^{-1}$ ) than the offshore (av. $3 \pm 2 \mathrm{mgC} \mathrm{m}^{-3} \mathrm{~d}^{-1}$ and av. $198 \pm 43 \mathrm{mgC} \mathrm{m}^{-2} \mathrm{~d}^{-1}$ ). The abundance of phytoplankton in the surface waters was also higher in the inshore region (av. $685 \pm$ $321 \times 10^{4}$ cells $\mathrm{m}^{-3}$ ) compared to the offshore (av. $659 \pm 920 \times 10^{4}$ cells $\mathrm{m}^{-3}$ ). Similar to the SIM period, Trichodesmium erythraeum was the most abundant phytoplankton during the OSM. The dominant diatoms in the inshore and offshore regions showed only marginal compositional changes. The abundance of dominant phytoplankton in the inshore waters was Trichodesmium erythraeum (av. 4884 x $10^{3}$ cells $\mathrm{m}^{-3}$ ) $>$ Rhizosolenia alata (av. $408 \times 10^{3}$ cells $\mathrm{m}^{-3}$ ) $>$ Coscinodiscus radiatus (av. $208 \times 10^{3}$ cells $\mathrm{m}^{-3}$ ) > Nitzschia seriata (av. $89 \times 10^{3}$ cells $\mathrm{m}^{-3}$ ) $>$ Thalassionema nitzschiodes (av. $68 \times 10^{3}$ cells $\mathrm{m}^{-}$ ${ }^{3}$ ) $>$ Bacillaria paradoxa (av. $16 \times 10^{3}$ cells $\mathrm{m}^{-3}$ ). In the offshore region the order of abundance was Trichodesmium erythraeum (av. $4640 \times 10^{3}$ cells $\mathrm{m}^{-3}$ ) $>$ Rhizosolenia alata (av. $166 \times 10^{3}$ cells $\mathrm{m}^{-3}$ ) > Diploneis sp. (av. $24 \times 10^{3}$ cells $\mathrm{m}^{-3}$ ) $>$ Thalassionema nitzschiodes (av. $68 \times 10^{3}$ cells $\mathrm{m}^{3}$ ) $>$ Nitzchia pungens (av. $4 \times 10^{3}$ cells $\mathrm{m}^{-3}$ ). There was a high occurrence of larger diatoms Rhizosolenia alata, Coscinodiscus radiatus, Nitzschia seriata, Thalassionema nitzschiodes in the inshore waters.

\subsubsection{PSM}


The study period was characterized by the highest amount of integrated chlorophyll $a$ (av. $29 \pm$ $20.5 \mathrm{mg} \mathrm{m}^{-3}$ ) and primary production (av. $335 \pm 278 \mathrm{mgC} \mathrm{m}^{-2} \mathrm{~d}^{-1}$ ) (Table 1, Fig. 6). The surface and integrated chlorophyll $a$ in the inshore region (av. $1.12 \pm 0.69 \mathrm{mg} \mathrm{m}^{-3}$ and av. $41 \pm 23 \mathrm{mg} \mathrm{m}^{-2}$ ) was markedly higher than that in the offshore (av. $0.36 \pm 0.23 \mathrm{mg} \mathrm{m}^{-2}$ and av. $17 \pm 7.4 \mathrm{mg} \mathrm{m}^{-2}$ ). The inshore chlorophyll $a$ values during the PSM (av. $1.1 \pm 0.6 \mathrm{mg} \mathrm{m}^{-3}$ and av. $41 \pm 23 \mathrm{mg} \mathrm{m}^{-2}$ respectively) was much higher than the corresponding values during the SIM (av. $0.3 \pm 0.2 \mathrm{mg} \mathrm{m}^{-3}$ and av.15 $\pm 8 \mathrm{mg} \mathrm{m}^{-2}$ respectively) and OSM (av. $0.3 \pm 0.1 \mathrm{mg} \mathrm{m}^{-3}$ and av. $21 \pm 8 \mathrm{mg} \mathrm{m}^{-2}$ respectively). Similarly, the surface and integrated primary production in the inshore region during the PSM was markedly higher than the corresponding values during the SIM and OSM (Table 1). The surface phytoplankton abundance showed a clear increase in the inshore region (av. $1493 \pm 1107 \times 10^{4}$ cells $\mathrm{m}^{-3}$ ) than the offshore (av. $571 \pm 394 \times 10^{4}$ cells $\mathrm{m}^{-3}$ ). Nitzschia seriata (av. $1468 \times 10^{3}$ cells $\mathrm{m}^{-3}$ ) was the most dominant phytoplankton in the inshore waters whereas Trichodesmium erythraeum was the dominant one in the offshore region (av.1460 x $10^{3}$ cells $\mathrm{m}^{-3}$ ). Dominant diatoms in the inshore waters were generally larger in size with the following order of abundance Nitzschia seriata (av. $1468 \times 10^{3}$ cells $\mathrm{m}^{-3}$ ) $>$ Rhizosolenia alata (av. $728 \times 10^{3}$ cells $\mathrm{m}^{-3}$ ) $>$ Chaetoceros socialis (av. $544 \times 10^{3}$ cells $\mathrm{m}^{-3}$ ) $>$ Thalassionema nitzschiodes (av. $304 \times 10^{3}$ cells $\mathrm{m}^{-3}$ ) $>$ Biddulphia rhombus (av. $204 \times 10^{3}$ cells $\mathrm{m}^{-3}$ ) $>$ Chaetoceros $s p$. (av. $166 \times 10^{3}$ cells $\mathrm{m}^{-3}$ ) $>$ Thalassiosira (av.168 $\times 10^{3}$ cells $\mathrm{m}^{-3}$ ) > Pleurosigma directum (av. $136 \times 10^{3}$ cells $\mathrm{m}^{-3}$ ). The dominant diatoms in the offshore region were in the following order of abundance Chaetoceros affinis (av. $376 \times 10^{3}$ cells $\mathrm{m}^{-3}$ ) $>$ Rhizosolenia alata (av. $73 \times 10^{3}$ cells $\mathrm{m}^{-3}$ ) > Thalassionema sp. (av.15 x $10^{3}$ cells $\mathrm{m}^{-3}$ ) $>$ Bacillaria paradoxa (av.14 x $10^{3}$ cells $\mathrm{m}^{-3}$ ).

\subsection{Microzooplankton}

\subsubsection{Composition}

The protozoan component of microzooplankton consisted of heterotrophic dinoflagellates, ciliates and sarcordines in which the first two groups were predominant during all the observations. Heterotrophic dinoflagellates contributed substantially to the total abundance of MZP (av. 59 - 68 \% during these periods). Altogether 25 species of heterotrophic dinoflagellates were recorded during the study and the dominant genera were Protoperidinium, Phalacroma and Ornithocercus (Table 2). The seasonal variation in the total abundance of heterotrophic dinoflagellates species was only marginal (20 - 21 species). Over all, ciliates formed the second abundant group in the MZP community. However, the number of species of ciliates (42 species belonging to 26 genera) was much higher than that of the heterotrophic dinoflagellates (26 species belonging of 6 genera) (Table 2). The seasonal variation in number of ciliate species was prominent with the highest number (32 species) during SIM followed by OSM (30 species) and PSM (6 species) (Table 3). 


\subsubsection{Abundance and species diversity}

The mean abundance of MZP in the inshore and offshore regions during SIM period (av. $230 \pm$ $66 \times 10^{3}$ ind. $\mathrm{m}^{-3}$ and av. $251 \pm 155 \times 10^{3}$ ind. $\mathrm{m}^{-2}$, respectively) was higher compared to the OSM (av. $141 \pm 114 \times 10^{3}$ ind. $\mathrm{m}^{-2}$ and $69 \pm 37 \times 10^{3}$ ind. $\mathrm{m}^{-2}$, respectively) and PSM (av. $186 \pm 247 \times 10^{3}$ ind. $\mathrm{m}^{-2}$ and $183 \pm 88 \times 10^{3}$ ind. ${ }^{-2}$, respectively) (Fig. 7). The peak abundance of MZP during the entire study period was found at $10^{\circ} \mathrm{N}$ during PSM. This was due to the exceptionally high abundance of heterotrophic dinoflagellates at this location (Fig. 8). During the PSM, the mean abundance of heterotrophic dinoflagellates was higher compared to SIM and OSM (Fig. 8) whereas, ciliates was the highest during the SIM. The abundance of ciliates decreased from SIM (av. $40 \pm 18 \times 10^{3}$ ind. $\mathrm{m}^{-3}$ in the inshore and $65 \pm 30 \times 10^{3}$ ind. $\mathrm{m}^{-2}$ in the offshore) to OSM (av. $27 \pm 13 \times 10^{3}$ ind. $\mathrm{m}^{-2}$ and $30 \pm 19 \times 10^{3}$ ind. $\mathrm{m}^{-2}$ respectively) and PSM (av. $3 \pm 5 \times 10^{3}$ ind. $\mathrm{m}^{2}$ and $30 \pm 19 \times 10^{3}$ ind. $\mathrm{m}-2$ respectively) (Fig. 7 \& 8). The abundance of crustacean nauplii was higher during SIM period (av. $115 \pm 53 \times 10^{3}$ ind. $\mathrm{m}^{-2}$ in the inshore and $13 \pm 144 \times 10^{3}$ ind. $\mathrm{m}^{-2}$ in the offshore) compared to OSM (av. $2 \pm 4 \times 10^{3}$ ind. $\mathrm{m}^{-2}$ in the inshore and $1 \pm 1 \times 10^{3}$ ind. $\mathrm{m}^{-2}$ in the offshore) and PSM (av. $6 \pm 9 \times 10^{3}$ ind. $\mathrm{m}^{-2}$ in the inshore and $9 \pm 7 \times 10^{3}$ ind. $\mathrm{m}^{-2}$ in the offshore region) (Fig. 7). Throughout the study sarcordines were found to be numerically less in abundance (av. $3 \pm 2 \%$ ). The crustacean larvae contribution to the total abundance of MZP was low during the monsoon periods, (av. $6 \pm 4 \%$ ) but there was a marked increase in their abundance during the SIM (Fig. 7).

Over all, the species richness, evenness and diversity of MZP were higher during the SIM and OSM compared to PSM (Fig. 9). The diversity, richness and evenness of ciliates were the least during the PSM. The evenness of ciliates and heterotrophic dinoflagellates were markedly higher during the SIM and OSM compared to PSM. The richness and diversity of heterotrophic dinoflagellates was evidently higher during the OSM and PSM compared to the SIM (Fig. 9). MDS analysis using species abundance data of ciliates and heterotrophic dinoflagellates showed similarity in species abundance at different locations during the SIM whereas such clear grouping of locations was not evident during monsoon periods (Fig. 10a). Heterotrophic species abundance at locations 1, 2, 3, 6,7 and 8 showed similarity. Similarly, ciliates species abundance at locations 1, 2, 3, 4, 8 and 9 also showed similarity. In order to see the species resulting in such a grouping of locations based on species similarity, we analyzed the result of hierarchical clustering of species data (Fig. 10b). Two major clusters were evident in the cluster plots (at $40 \%$ similarity level) formed of 10 species of heterotrophic dinoflagellates and 12 species of ciliates respectively. The heterotrophic dinoflagellates cluster was formed of Dinophysis hastata, Ornithocercus quadratus, O. magnificus, O. steinii, Phalacroma rapa, P. apicatum, P. doryphorum, Podolampus spinifera, P. palmipes and Protoperidinium divergens. The ciliate species 
cluster was formed of Codonellopsis tesselata, Epiplocylis undella, Eutintinnus lusus undae, E. elongates, Proplectella globosa, Rhabdonella spiralis, Salpingella decurtata, S. acuminata, Salpingacantha ampla, Undella globosa, Protorhabdonella simplex and Xystonella trefortii.

\section{4. Mesozooplankton (MSP)}

The mesozooplankton biomass was found to be high during the PSM (av. $245 \pm 293 \mathrm{ml} 100 \mathrm{~m}^{-}$

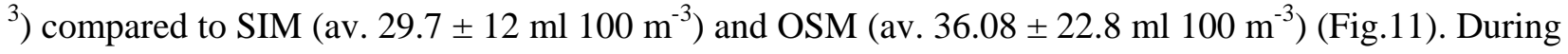
the PSM, marked enhancement in zooplankton biomass was evident in the inshore locations south of $13^{\circ} \mathrm{N}$. Major zooplankton groups recorded are shown in Table 4. Nine groups formed the majority of the zooplankton community during the SIM (av. $96 \pm 6$ \%), OSM (av. $96 \pm 7 \%$ ) and PSM (av. $98 \pm 2 \%$ ). Copepods formed the most dominant followed by chaetognaths, ostracods and siphonophores in which copepods alone formed the bulk (>80\%) of the total abundance. During all the three sampling periods, majority of zooplankton groups showed higher abundance in the inshore waters compared to the offshore (Table 4). During the PSM, the abundance of copepods, chaetognaths, ostracods, siphonophores and euphausids were higher than SIM and OSM (Table 4). The increase in abundance of these groups during PSM was more pronounced in the inshore waters compared to the offshore. The highest abundance of copepods, chaetognaths and siphonophores were recorded in the inshore location of $10 \mathrm{~N}$ followed by 11.5 and $8^{\circ} \mathrm{N}$ during the PSM (Table 4).

\section{Discussion}

\subsection{Hydrographical features}

The hydrography during the SIM period was characterized by stratification due to prevalence of low saline $(<34.2)$ and warm $\left(>30^{\circ} \mathrm{C}\right)$ water in the inshore regions which was in concurrence with several earlier studies (Muraleedharan and Prasannakumar et al., 1996; Sanilkumar et al., 2003). The high amount of solar radiation, weak winds and presence of low salinity Bay of Bengal water had apparently caused a shallow mixed layer in the study area. The combined effect of these factors resulted in the formation of 'warm pool' in the southeastern Arabian Sea during the SIM period (Sanilkumar et al., 2003). A major consequence of the surface layer stratification is the depletion of nitrate in the surface layers (de Souza et al., 1996; Bhattathiri et al., 1996) and this feature was observed during the SIM period of the present study also (nitracline was at $60 \mathrm{~m}$ depth). In contrast to nitrate depletion, dissolved oxygen concentration was higher in the surface waters during the SIM period (av.200 $\mu \mathrm{M} \mathrm{L}^{-1}$ ), as compared to PSM (av. $180 \mu \mathrm{M} \mathrm{L}^{-1}$ ) possibly due to a lower amount of biological decomposition as suggested by Jyothibabu et al., 2006. This environmental conditions during 
the SIM caused low primary production and chlorophyll $a$ in both inshore and offshore regions (av.164 $\mathrm{mgCm}^{-2} \mathrm{~d}^{-1}$ and av. $128 \mathrm{mgCm}^{-2} \mathrm{~d}^{-1}$ respectively; av. $15 \mathrm{mgm}^{-2}$ and av.24 $\mathrm{mgm}^{-2}$ respectively).

Upwelling begins in the inshore locations of the southern transects ( 8 and $10^{\circ} \mathrm{N}$ ) with the OSM period. This is clearly visible in the vertical structure of temperature, salinity, dissolved oxygen and nutrients with the upsloping of isolines along these transects in the inshore region. During the southwest (summer) monsoon, the southward flowing West Indian Coastal Current brings high salinity waters into the southeastern Arabian Sea (Shankar et al., 2002a). Nutrient enrichment in the inshore region due to coastal upwelling caused enhancement of chlorophyll $a$ and primary production, but oligotrophic conditions similar to the SIM persisted in the offshore region (Figure 6). Nonetheless, the offshore primary production during the OSM was found to be higher (av. $198 \mathrm{mgCm}^{-2} \mathrm{~d}^{-1}$ ) than the SIM (av. $1251 \mathrm{mgC} \mathrm{m}^{-2} \mathrm{~d}^{-1}$ ), and this may be due to relatively more availability of nutrients in the surface waters during the former period.

Shallow MLD $(<15 \mathrm{~m})$, cold $\left(\sim 26^{\circ} \mathrm{C}\right)$ temperatures, and nutrient rich $\left(\mathrm{NO}_{3}>2 \mu \mathrm{M}\right)$ surface waters observed between 8 and $15^{\circ} \mathrm{N}$ during PSM were due to intense upwelling. The high nutrient concentration in the surface waters caused pronounced enhancement in chlorophyll $a$ (av. $41 \pm 23 \mathrm{mg}$

$\mathrm{m}^{-2}$ ) and primary production (av. 613 $459 \mathrm{mgC} \mathrm{m}^{-2} \mathrm{~d}^{-1}$ ). The highest chlorophyll $a\left(69 \mathrm{mg} \mathrm{m}^{-2}\right.$ ) and

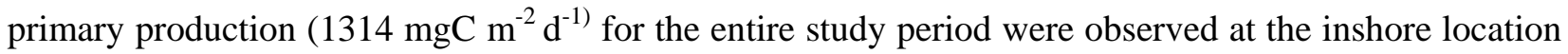
of $11.5^{\circ} \mathrm{N}$ during the PSM. At this location the surface nitrate content was exceptionally high $(1 \mu \mathrm{M})$ inducing the growth of phytoplankton and primary production (Bhattathiri et al., 1996).

\subsection{Response of phytoplankton}

During the SIM period, as a result of stable environmental conditions and stratification, Trichodesmium erythraeum occurred in exceptionally high abundance $\left(40-144 \times 10^{5}\right.$ cells $\mathrm{m}^{-3}$ ) especially in the offshore locations as has been explained before (Madhupratap et al., 1990; Nair et al., 1992). This high abundance of Trichodesmium erythraeum could be one of the important reasons for the high chlorophyll $a$ concentration found in the offshore region. Stable environmental conditions (calm sea, high transparency and temperature) are conducive for the development of Trichodesmium blooms (Carpenter, 1993; Capone et al., 1998; Jyothibabu et al., 2003). Most of these conditions are typical of the southeastern Arabian Sea during the SIM period (Krishnan et al., 2007). The other dominant phytoplankton genera that occurred in the study area such as Rhizosolenia, Coscinodiscus and Leptocylindrus are relatively small in size. This corroborates earlier finding that during SIM period cyanobacteria and smaller diatoms numerically dominate in the Arabian Sea, taking advantage of the 
intense stratification and nitrogen limitation (Jochem et al., 1993; Gordon et al., 1994; Campbell et al., 1998; Garrison et al., 2000; Brown et al., 2002).

During the OSM, the higher nutrient concentrations prevailing in the surface waters favoured an increase in the total abundance of phytoplankton from SIM period. Although there was an appreciable increase in the nutrient concentrations in many of the inshore locations during OSM compared to the offshore, phytoplankton abundance and species composition were more or less same in both regions. Trichodesmium erythraeum overall, dominated the phytoplankton community during the OSM followed by Rhizosolenia alata. This could primarily be due to similarity in environmental conditions during the SIM and OSM in a major part of the study area. In general, stratification and nitrate limitation in the surface waters were widespread during both the SIM and OSM. However, in a few inshore locations during the OSM, nutrient enrichment in the surface waters was evident due to upwelling. In these inshore locations, diatoms adapted to high nutrient environments belonging to Coscinodiscus, Thalassionema, Nitszchia and Chaetoceros (Subrahmanian, 1959; Sawant and Madhupratap., 1996) were the dominant phytoplankton.

As a response to nutrient-enriched conditions during the PSM, the phytoplankton community existing in the OSM in the inshore locations shifts to a greater dominance of larger individuals, particularly diatoms (Landry et al., 1997). This was found to be true during the present study also since a pronounced enhancement of phytoplankton abundance was found in the inshore waters during the PSM period. Taking advantage of the high nutrient concentration available in the surface waters during the PSM period, diatoms belonging to the genera Nitszchia, Rhizosolenia, Chaetoceros, Biddulphia and Thalassionema proliferated in the inshore regions.

The seasonal occurrence of Trichodesmium erythraeum in the eastern Arabian Sea has been well documented (Devassy et al., 1978; Krishnan et al., 2007). The literature suggests that the occurrence of this species in the Arabian Sea is strictly seasonal and restricted to the SIM period. However, the present study shows that it was widespread in the entire southeastern Arabian Sea during the SIM and OSM seasons and in the offshore region during the PSM. Our observation certainly warrants revising our traditional belief that $T$. erythraeum occurs only during SIM period. The present observation implies that even during the upwelling period a resident stock of $T$. erythraeum occur in the Arabian Sea. Obviously, temperature $>28{ }^{\circ} \mathrm{C}$, which are favourable for Trichodesmium blooms prevail in most parts of the eastern Arabian Sea during the SIM and OSM and in the offshore locations during the PSM. In recent years, the incidences of T. erythraeum along the east and west coasts of India have increased considerably (Jyothibabu et al., 2002, Krishnan et al., 2007, Habeebrehman et al., 2007), 
which may be linked to the increasing atmospheric temperature due to global warming as suggested by Ramos et al., (2005).

\subsection{Response of MZP and mesozooplankton}

The availability of preferential food and a warm condition are the key factors, which favor the MZP abundance in marine ecosystems (Heinbokel, 1978; Taniguchi and Kawakami, 1983; Verity, 1986; Godhantaraman and Krishnamurthy, 1997). Heterotrophic dinoflagellates dominate the MZP community of tropical and temperate waters due to their ability to utilize a wide size range of prey through diverse feeding mechanisms (reviews by Gains and Elbrachter, 1987; Hansen, 1991; Lessard, 1991; Stoecker and Capuzzo, 1999). In the present study, the relative abundance of heterotrophic dinoflagellates was the highest during the PSM followed by OSM. The species richness and diversity of heterotrophic dinoflagellates was evidently higher during the OSM and PSM compared to the SIM. This seasonal feature could be due to the ability of heterotrophic dinoflagellates to feed on larger diatoms which were more abundant during the OSM and PSM. The highest diversity, richness and evenness of ciliates were found during the SIM which could be linked to the high availability of smaller phytoplankton cells as a result of surface stratification (Cushing, 1989; Yentsch and Phinney, 1995; Jyothibabu et al., 2008 a \& b). The low relative dominance of ciliates during the PSM may also be linked to their inability to feed on larger cells. Abundance of ciliates (particularly tintinnids) in marine systems is related to the availability of smaller phytoplankton (Godhantaraman and Krishnamuthy, 1997; Heinboeckel et al., 1979). The high abundance of crustacean nauplii during the SIM period could be linked to the high availability of picoplankton, the major preferred food source of invertebrate larval forms (Roff et al., 1995)

The results of diversity analyses clearly showed that species evenness of both ciliates and heterotrophic dinoflagellates were markedly higher during the SIM and OSM compared to PSM. This could be attributed to the more homogenous environmental conditions prevailed during the SIM and OSM compared to the PSM (Jyothibabu et al., 2008a). MDS analysis using species abundance data of ciliates and heterotrophic dinoflagellates showed marked similarity in species abundance at different locations during the SIM. Prevalence of similar environmental conditions and phytoplankton food availability in various locations during the SIM caused due to surface stratifications could be the possible reason for the observed similarity in species abundance. The phytoplankton cells in strongly stratified marine environments are smaller compared to those in relatively less stratified conditions (Johnson and Sieburth, 1979; Platt, 1983; Cushing, 1989; Yentsch and Phinney, 1995).

The higher mean abundance of MZP during the SIM period compared to the OSM and PSM observed during this study was in agreement with the results of earlier studies from the Arabian Sea 
(Gauns et al., 1996) and Bay of Bengal (Jyothibabu et al., 2008a). However, the highest abundance of MZP for the entire study period was observed in the inshore location of $10^{\circ} \mathrm{N}$ during PSM. The high MZP abundance in the inshore region of $10^{\circ} \mathrm{N}$ transects was also reported in two earlier studies (Gauns et al., 1996; Jyothibabu et al., 2008b). This could be due to the influx of Cochin backwaters which is the largest estuarine system along the west coast of India and rich in microzooplankton community (Jyothibabu et al., 2006).

It is significant to note that ciliates in the inshore region were declining with the progression of the seasons (SIM to PSM). This could possibly be due to the predominance of smaller phytoplankton during the SIM period and progressive increase of larger diatoms from SIM to PSM. The high biomass and abundance of phytoplankton lead to high abundance of mesozooplankton grazers such as copepods. Many of these grazers are omnivores and consume ciliates as an important nutritional requirement (Robertson, 1983). Several studies have suggested that even many of the carnivorous zooplankton may also prey up on MZP (Stoecker and Capuzzo, 1990; Fukami et al., 1999). The substantial increase in the abundance and biomass of copepods and many other mesozooplankton during the PSM would be a causative factor for the low abundance of the MZP community during the PSM due to high predation pressure (top down control).

It is important to see that the mesozooplankton community in terms of biomass and abundance was low during the SIM and OSM compared to PSM. This could primarily be due to the relatively low phytoplankton production during the SIM and OSM. Due to stratified environmental conditions, majority of the phytoplankton biomass during these periods is contributed by pico/nanoplankton which favors a dominant herbivorous microbial food web (Azam et al., 1983). Thus the MZP abundance and abundance increase during the stratified conditions. However, the total exploitable carbon available for mesozooplankton (large phyto + MZP) during these periods would be lesser compared to the PSM (Jyothibabu et al., 2008a). This situation eventually causes the highest MZP abundance and the lowest mesozooplankton biomass during the SIM.

\section{Conclusion}

Stratification due to warm $\left(>30^{\circ} \mathrm{C}\right)$ and low salinity $(<34.2)$ waters during the SIM caused depletion of nitrate in the surface waters leading to low chlorophyll $a$ and primary production. Mean MZP abundance and diversity was higher during SIM compared to the OSM and PSM, probably because of the presence of abundant smaller phytoplankton cells due to nitrogen depletion. The MZP community was characterized by the numerical dominance of heterotrophic dinoflagellates in most of the stations during the PSM due to their ability to graze large diatoms. However, the abundance of 
ciliates decreased from SIM (av. $52.8 \pm 26.6825 \times 10^{3}$ ind. $\mathrm{m}^{-2}$ ) through the OSM (av.28 $\pm 15 \times 10^{3}$ ind. $\mathrm{m}^{-2}$ ) to the PSM (av. $19.2 \pm 34 \times 10^{3}$ ind. $\mathrm{m}^{-2}$ ) probably due to the low abundance of smaller phytoplankton (causing low abundance of ciliates) and high stock of mesozooplankton grazers

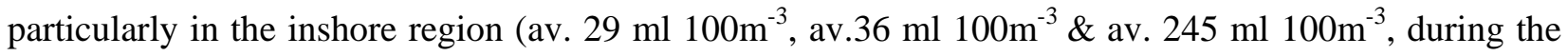
PSM, OSM and PSM respectively). This paper demonstrates that the MZP community is less prominent in the eastern Arabian Sea during the southwest monsoon season (high phytoplankton biomass and production) probably due to the exceptionally high stock of mesozooplankton predators.

\section{Acknowledgements}

We are thankful to the Director, National Institute of Oceanography, India for the facilities provided. Our thanks are due to the Director, Centre for Marine Living Resources and Ecology, Kochi, India for the financial support to the Research Project 'Marine Research - Living Resource Assessment Programme’ to which the present work is related. We are also grateful to Dr. K. K. Balachandran for the preliminary review of this manuscript. This is National Institute of Oceanography contribution XXXXX

\section{Reference}

Azam, F.T., Fenchel, J.G., Field, J.S., Gray, L.A., Mayer, R., Thingstad, F., 1983. The ecological role of water column microbes in the Sea. Marine Ecology Progress Series 10, 257 - 263.

Banse, K., Sumitra Vijayaraghavan, Madhupratap, M., 1996. On the possible causes of the seasonal phytoplankton bloom along the southwest coast of India. Indian Journal of Marine Sciences 25, 283289.

Bhattathiri, P.M.A., Pant, A., Sawant, S., Gauns, M., Matondkar, S.G.P., Mohanraju, R., 1996. Phytoplankton production and chlorophyll distribution in the eastern and central Arabian Sea in 1994 1995. Current Science 71, 869- 877.

Brown, S.L., Landry, M.R., Christensen, S., Garrison, D., Gowing, M.M., Bidigare, R.R., Campbell, L., 2002. Microbial community dynamics and taxon-specific phytoplankton production in the Arabian Sea during the 1995 monsoon seasons. Deep-Sea Research II 49, 2345-2376.

Burkill, P.H., Edwards, E.S., John A.W.G., and Sleigh M.A. 1993a. Microzooplankton and their herbivorous activity in the northeastern Atlantic Ocean. Deep Sea Research 40, 479 - 493. 
Burkill, P.H., Leaky, R.J.G., Owens, N.J.P., and Mantoura, R.F.C., 1993b. Synechococcus and its importance to the microbial food web of the northwestern Indian Ocean, In: Biogeochemical Cycling in the Northwestern Indian Ocean, (ed. Burkill, P.H., Mantoura, R.F.C. and Owens, N. J. P) 40, 3.

Campbell, L., Landry, M.R., Constantinou, J.C., Nolla, H.A., Brown, S.L., Liu, H., Caron, D., 1998. Response of microbial community structure to environmental forcing in the Arabian Sea. Deep-Sea Research II 45, 2301-2325.

Capone, D.G., Zehr, J.P., Pearl, H.W., and Carpenter, E.J. 1998. Trichodesmium, a significant marine cyanobacterium. Science 276, 1221-1229.

Carpenter, E.J., O’Neil, J.M., Dawson, R., Capone, D.G., Siddiqui, P.J.A., Roenneberg, T., Bergman, B., 1993. The tropical diazotrophic phytoplankter Trichodesmium: biological characteristics of two common species. Marine Ecology Progress Series 95, 295-304.

Clarke, K. R., Gorley, R.N., 2001. PRIMER (Plymouth Routine In Multivariate Ecological Research) V5 : User Mannual / Tutorial. 90pp.

Corliss, J.O., 1979. In the Ciliated Protozoa, Characterisation, classification and guide to literature, Pergamon Press, New York. 2, pp. 455.

Cushing, D.H., 1989. A difference in structure between ecosystems in strongly stratified waters and in those that are only weakly stratified. Journal of Plankton research 11, 1-13.

de Souza, S.N., Dileep Kumar, M., Sardesai, S., Sarma, V.V.S.S., Shirodkar, P.V., 1996. Seasonal Variability in oxygen an nutrients in the central and eastern Arabian Sea. Current Science 71, 847-851

Devassy, V.P., Bhattathiri, P.M.A., Qasim, S.Z., 1978. Trichodesmium phenomenon. Indian Journal of Marine Sciences 7, 168- 186.

Dussart, B.N. 1963. Les differentes categories de plankton. Hydrobiologia , 26: 72-74.

Froneman, P.W., McQuaid , C.D., 1997. Preliminary investigation of the ecological role of microzooplankton in the Kariega estuary, South Africa. Estuarine Coastal and Shelf Science 45, 689 695.

Fukami, K., Watanable, A., Fujitha, S., Yamoka, K., Nishijima, T., 1999. Predation on naked protozoan microzooplankton by fish larvae. Marine Ecology Progress Series 185, 285 - 291. 
Gains, G., Elbrachter, M., 1987. Heterotrophic nutrition. In Biology of dinoflagellates, In FJR Taylor (ed.), Blackwell Scientific Publications, Oxford, 224 - 268.

Garrison, D.L., Gowing, M.M., Hughes, M.P., Campbell, L., Caron, D.A., Dennett, M.R., Shalapyonok, A., Olson, R.J., Landry, M.R., Brown, S.L., Liu, H., Azam, F., Steward, G.F., Ducklow, H.W., Smith, D.C., 2000. Microbial food web structure in the Arabian Sea: a US JGOFS study. DeepSea Research II 47, 1387-1422.

Gauns, M., Mohanraju, R., Madhupratap, M., 1996. Studies on the microzooplankton from the central and eastern Arabian Sea. Current Science 71, 874 - 877.

Gifford, D.J., Dagg, M.J., 1991. The microzooplankton- mesozooplankton link: consumption of planktonic protozoa by the calanoid copepods Acartia tonsa Dana and Neocalanus plumchrus Murukawa. Marine Microbial Food Webs 5, 161-177.

Gifford, D.J, Caron, D.A., 2000. Sampling, preservation, enumeration and biomass of marine protozooplankton. ICES zooplankton methodology manual, Academic Press, 193-213.

Godhantaraman, N., Uye, S., 2004. Geographical and seasonal variations in taxonomic composition, abundance and biomass of microzooplankton across a brackish-water lagoonal system of Japan. Journal of Plankton Research 25, 465 - 482.

Godhantaraman, N., Krishnamurthy, K., 1997. Experimental studies on food habits of tropical microzooplankton (prey - predator interrelationship). Indian Journal of Marine Sciences 26, 345 - 349.

Gordon, N., Angel, D.L., Noeri, N., Kress, N., Kimor, B., 1994. Heterotrophic dinoflagellates with symbiotic cyanobacteria and nitrogen limitation in the Gulf of Aquaba, Marine Ecology Progress Series $107,83-88$.

Grassholf, K., Ehrhardt, M., Kremling, K., 1983. Methods of Seawater Analysis, In: Grassholf, K., Ehrhardt, M., Kremling, K (eds.). (Verlag Chemie, Weinheim), 89 - 224.

Habeebrehman, H., Prabhakaran, M.P., Josia Jacob, Sabu P., Jayalakshmi, K.J. , Achuthankutty, C.T. , Revichandran, C. 2008. Variability in biological responses influenced by upwelling events in the Eastern Arabian Sea, Journal of Marine Systems,74, 545-560. 
Hansen, P.J., 1991. Quantitative importance and trophic role of HDS in a coastal pelagic food web. Marine Ecology Progress Series 73, 253 - 273.

Heips, C., 1974. A new index measuring evenness, Marine Biological Association, UK, 54, 555 - 557. Heinbokel, J.F., Beers, J.F., 1979, Studies on the functional role of tintinnids in the Southern California Bight. II. Grazing rates of field populations. Marine Biology 47, 191-197.

Jochem, F.J., Pollehne, F., Zeitzschel, B., 1993. Productivity regime and phytoplankton size structure in the Arabian Sea. Deep-Sea Research 40, 711-735.

Johnson, P.W., Sieburth, JMcN., 1979. Chrococcoid cyanobacteria in the sea: a ubiquitous and diverse phototrophic biomass. Limnology and Oceanography 24, 1928 - 1935.

Jorgensen, E., 1924. Mediterranean Tintinnidae. Reports on the Danish Oceanographical expeditions 1908 - 1910 to the Mediterranean and adjacent seas II (Biology), J.3.Andr Fred Host \& Son, Copenhagen.

Jyothibabu , R., Madhu, N.V., Nuncio, M., Haridas, P.C., Nair, K.K.C., Venugopal, P., 2003. Intense blooms of Trichodesmium erythraeum (Cyanophyta) in the open waters along the east coast of India. Indian Journal of Marine Sciences, 32, 165-167.

Jyothibabu, R., Madhu, N.V., Maheswaran, P.A., Nair, K.K.C., Venugopal, P., Balasubramanian, T., 2003. Dominance of dinoflagellates in microzooplankton community in the oceanic regions of the Bay of Bengal and the Andaman Sea. Current Science 84, 1247 - 1253.

Jyothibabu. R., Madhu, N.V., Jayalakshmi, K.V., Balachandran, K.K., Shiyas, C.A., Martin G.D., Nair, K.K.C., 2006. Impact of large river influx on microzooplankton and its implications on the food web of tropical estuary (Cochin backwaters - India). Estuarine, Coastal and Shelf Science 69, 505 -518.

Jyothibabu, R., Madhu, N.V., Maheswaran, P.A., Jayalakshmi, K.V., Nair, K.K.C and Achuthankutty, C.T., 2008a. Seasonal variation of microzooplankton $(20-200 \mu \mathrm{m})$ and its possible implications in the in the western Bay of Bengal. Continental Shelf Research 28, 737-755.

Jyothibabu, R., Asha Devi, C.R., Madhu, N.V., Sabu, P., Habeebrehman, H., Josia Jacob., Nair, K.K. C., 2008b. Response of microzooplankton $(20-200 \mu m)$ to the coastal upwelling and summer stratification in the southeastern Arabian Sea Continental shelf Research 28, 651-673. 
Kofoid, C.A., Campbell, A.S., 1939. Reports on the scientific results of the expedition to the Eastern Tropical Pacific, in charge of Alexander Agassiz, US Fish Commission steamer “Albatross”, from October 1904 to March 1905. University California Publications in Zoology 34, 1 - 403.

Krishnan, A.A. Krishnakumar, P.K., Rajagopalan, M., 2007. Trichodesmium erythraeum (Ehrenberg) bloom along the southwest coast of India (Arabian Sea) and its impact on the trace metal concentrations in the sea water. Estuarine Coastal and Shelf Science 71, 641-646.

Landry, M.R., Constantinou, J., Kirshtein, J., 1995. Microzooplankton grazing in the central equatorial Pacific during February and August 1992. Deep-Sea Research II 42, 657-671.

Landry, M.R., Barber, R.T., Bidigare, R.R., Chai, F., Coale, K.H., dam, H.G., Lewis, M.R., Lindley, S.T., McCarthy, J.J., Roman, M.R., Sroecker, D.K., Verity, P.G., White, J.R. 1997. Iron and grazing constraints on primary production in central equatorial Pacific and EqPac synthesis. Limnology and Oceanography 42, 405-418.

Landry, M.R., Brown, S.L., Campbell, L., Constantinou, J., Liu, H., 1998. Spatial pattern in phytoplankton growth and microzooplankton grazing in the Arabian Sea during monsoon forcing. Deep Sea Research 45, 2353-2368.

Lessard, E.J., 1991. The trophic role of heterptrophic dinoflagellates in diverse marine environments. Marine Microbial Food Webs 5, $49-58$.

Lynn, D.H., Montagnes, D.J.S., Small, E.B., 1988. Taxonomic descriptions of some conspicuous species in the Family Strombididae (Ciliophora: Oligotrichida) from the Isles of Shoals, Gulf of Maine. Journal of Marine Biology Association of United Kingdom, 68, 259 - 276.

Madhupratap, M., Nair, S.R.S., Haridas, P., Padmavati, G., 1990. Response of zooplankton to physical changes in the environment: coastal upwelling along central west coast of India, Journal of Coastal Research 6, 413-426.

Madhupratap, M., Gopalakrishnan, T.C., Haridas, P., Nair, K.K.C., Aavindakshan, Padmavati, G., Shiney Paul. 1996. Lack of seasonal and geographical variation in mesozooplankton biomass in the Arabian Sea and its structure in the mixed layer, Current Science 70, 863-869. 
Madhupratap, M., Nair, K.N.V., Gopalakrishnan, T.C., Haridas, P., Nair, K.K.C., Venugopal, P., Gauns, M., 2001. Arabian Sea Oceanography and fisheries of the west coast of India. Current Science $81,355-361$.

Maeda, M., 1986. An illustrated guide to the species of the family Halteridae and Strombilidae (Oligotrichida, Ciliopora), free swimming protozoa commom in aquatic environments. Bulletin Ocean Research Institute, University of Tokyo 19, pp. 68.

Maeda, M., Carey, P.G., 1985. An illustrated guide to the species of the family Strombidiidae (Oligotrichida, Ciliopora), free-swimming protozoa common in aquatic environments. Bulletin Ocean Research Institute, University of Tokyo, 19, pp.68.

Marshall, S.M. 1973. Respiration and feeding in copepods. Advances in Marine Biology, 11: 57 120.

Marshall, S., 1969. Protozoa, Order Tintinnida. Zooplankton sheet 127, Conseil International pour l' exploration de la mer. Mer. Fiches Ident. Zooplankton Fishe, 117 - 127.

Margalef, R., 1968, In: Perspectives in ecological theory. University of Chicago Press, 111 pp.

Miller, C.B., 1993. Pelagic production processes in the Subarctic Pacific. Progress in Oceanography 32, $1-15$.

Muraleedharan, P.M., Prasanna Kumar, S., 1996. Arabian Sea upwelling - A comparison between coastal and open ocean regions. Current Science 71, 842-846.

Nair, S.R.S., Devassy, V.P., Madhupratap, M., 1992. Blooms of phytoplankton along the west coast of India associated with nutrient enrichment and the response of zooplankton. Science of the total environment, Supplement, Elsevier Science Publishers B.V., Amsterdam, 819 - 828.

Nival, P., Nival, S., 1976. Particle retention efficiencies of herbivorous copepod Acartia clausi (adult and copepodite stages): effects of grazing. Limnology and Oceanography, 21, 24 - 38. 
Platt, T.,1983. Autotrophic picoplankton in the tropical ocean. Science, 219, 290 - 295.

Prasannakumar, S., Prasad, T.G., 1996. Winter cooling in the northern Arabian Sea. Current Science $71,834-841$.

Putland, J.N., 2000. Microzooplankton herbivory and bacterivory in Newfoundland coastal waters during spring, summer and winter. Journal of Plankton Research 22, 253 - 277.

Qasim, S.Z., 2003. Indian Estuaries (Allied publication Pvt. Ltd. Heriedia Marg, Ballard estate, Mumbai). pp. 259.

Ramos, A.G., Martel, A., Codd, G.A., Soler, E., Coca, J., Redondo, A., Morrison, L. F Metcalf, J.S., Ojeda, A., Suárez, S., Petit, M., 2005. Bloom of the marine diazotrophic cyanobacterium Trichodesmium erythraeum in the Northwest African Upwelling. Marine Ecology Progress Series 301, 303-305.

Robertson, J.R .1983. Predation by estuarine zooplankton on tintinnid ciliates. Estuar. Coast. Shelf Sci. 16: 27 - 36.

Roff, J.C., Turner, T.J., Webber, M.K., Russell R. Hopcroft, R.R., 1995. Bacterivory by tropical copepod nauplii: extent and possible significance, Aquatic Microbial Ecology 9, 165-175.

Sanilkumar, K.V., Hareeshkumar P.V., Joseph, J., Panigrahi, J.K., 2003. Arabian Sea mini warm pool during May 2000, Current Science 86, 180 - 184.

Sawant, S., Madhupratap, M., 1996. Seasonality and composition of phytoplankton in the Arabian Sea. Current Science 71, 869-873.

Shalapyonok, L.S., Oslon, R.J., Shalapyonok, L.S., 2001. Arabian Sea phytoplankton during southwest and northeast monsoons 1995: composition, size structure and biomass from individual cell properties measured by flow cytometry. Deep Sea Reasearch II 48, 1231 - 1261.

Shankar, D., Vinayachandran, P.N., Unnikrishnan, A.S., 2002.a The monsoon currents in the north Indian Ocean Progress in Oceanography 52, 63-120.

Shannon, C.E., Weaver, W., 1963. The mathematical theory of communication, University of Illinos. 
Steidinger, K.A., Williams, J., 1970. A memoir of the hourglass cruises - Dinoflagellates, Marine Research Laboratory, Florida, pp. 249.

Stelfox - Widdicombe, C.E., Archer, S.D., Burkill, P.H., Stefels, J., 2004. Microzooplankton grazing in phaeocystis and diatom dominated waters in the southern North Sea in spring. Journal of Sea Research $51,37-51$.

Stoecker, D.K, Capuzzo, J.M., 1990. Predation on Protozoa: its importance to zooplankton. Journal of Plankton Research 12, 891-908.

Strickland, J. D. H., Parsons, T. R., 1972. In: A Practical Handbook of Sea Water Analysis, second ed. Bulletin Fisheries Research of Board Canada 167, 310.

Subrahmanyan, R., 1959. Studies on the phytoplankton of the west coast of India-I and II. Proceedings of the Indian Academy of Science B50, 113-252.

Subrahmanyan, R, 1971. The Dinophycea of the Indian Seas, Memoir II, Part 2, Family Peridineacea, Marine Biological Association of India, Cochin, India.

Taniguchi, A., Kawakami, R., 1983. Growth rate of ciliates Eutintinnus lusus undae and Favella taraikaesis observed in laboratory culture experiments. Bulletin Plankton Society of Japan 30, 33-40.

Taylor F.J.R., 1987. Ecology of dinoflagellates: general and marine ecosystems. In Taylor, F. J. R (ed.). The biology of dinoflagellates. Blackwell Scientific Publications, Oxford, 399 - 501.

Taylor, F.J.R.,1976a. Dinoflagellates from the Indian Ocean expedition - A report on the material collected by the R. V. 'Anton Brunn', 1963 - 1964. Institute of Oceanography and Department of Botany, University of British Columbia, Vancouver, Canada, pp. 46.

Taylor, F.J.R.,1976b. General feature of the dinoflagellate material collected by the 'Anton Brunn' during the international Indian Ocean expedition., Biology of the Indian Ocean, 155 - 169.

Tomas, C.R., 1997. Identifying Marine Phytoplankton. Academic Press, USA, pp. 858 
UNESCO, 1994. Protocols for the Joint Global Ocean Flux Study (JGOFS). Core Measurements, IOC Manuals and Guides 29, UNESCO, Paris, pp. 170.

Verity, P.G., 1986. Grazing on phototrophic nanoplankton by microzooplankton in the Narragansett Bay, Rhod Island. Marine Ecology Progress Series 29, 105-115.

Verity, P.G., Stoeker, D.K., Seiriacki M.E., Nelson, J.R., 1993. Grazing, growth, mortality of microzooplankton during the 1989 North Atlantic spring bloom at $47^{0}$ N, 180W. Deep Sea Research 40, 1793 - 1814.

Yentsch, C.S., Phinney, D.A., 1995. Two pathways of primary production induced by monsoon wind forcing. In: Arabian Sea: Living Marine Resources and the Environment. Thomson, M.F., \& Tirmizi, N.M. (eds). Vangard Books, Lahore, Pakistan 469 - 478. 


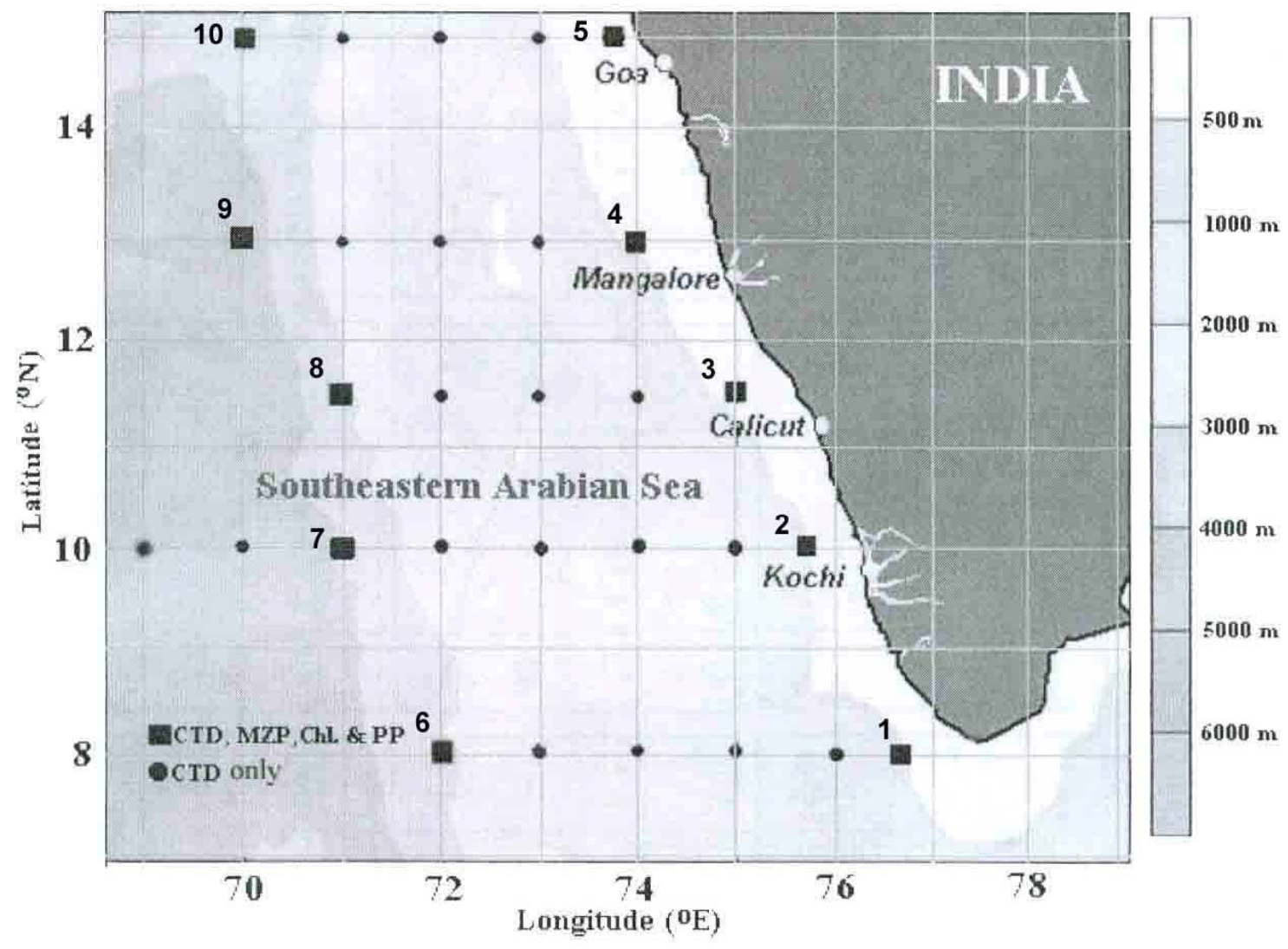

Figure 1 


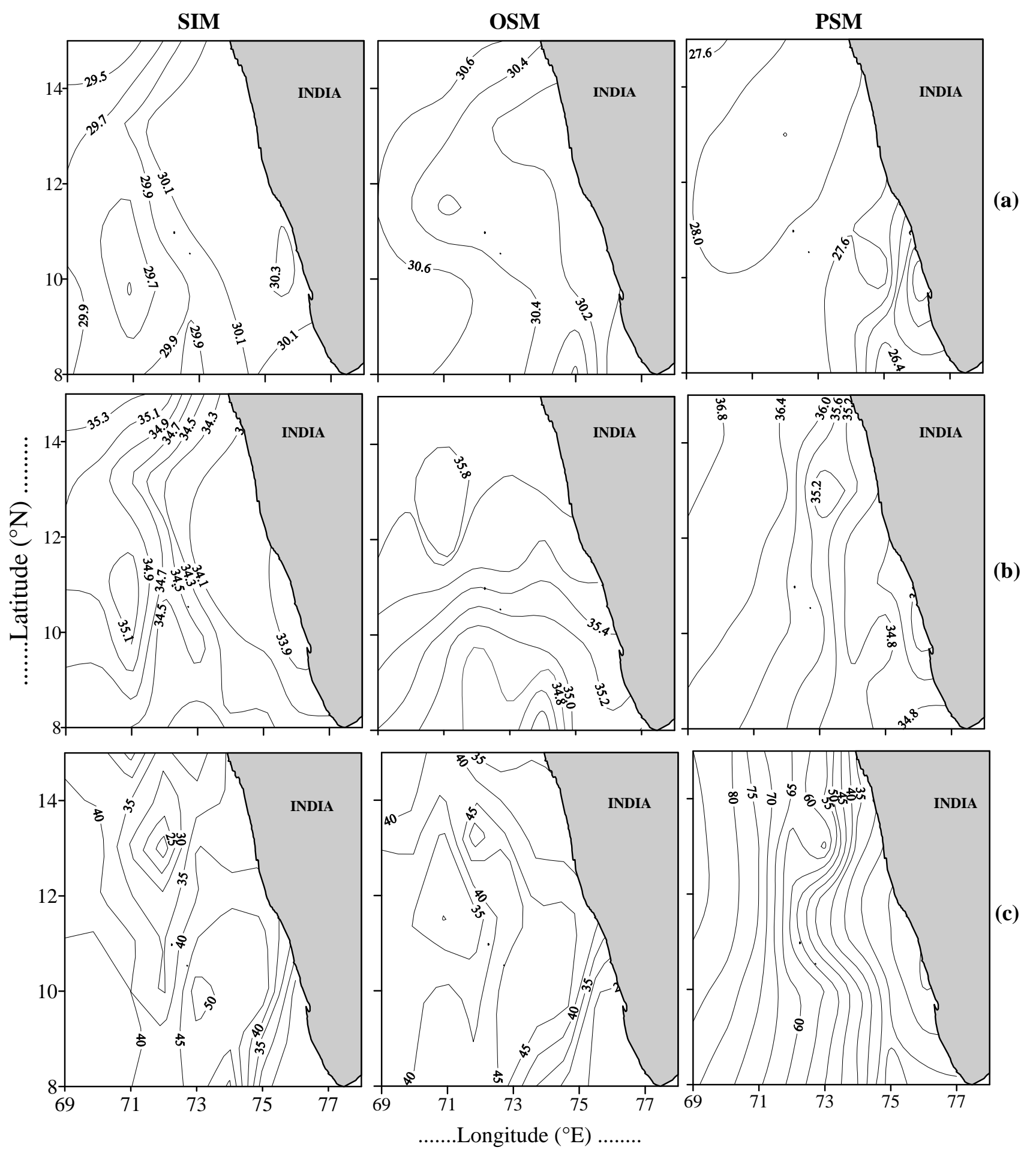

Figure 2 




Figure 3 


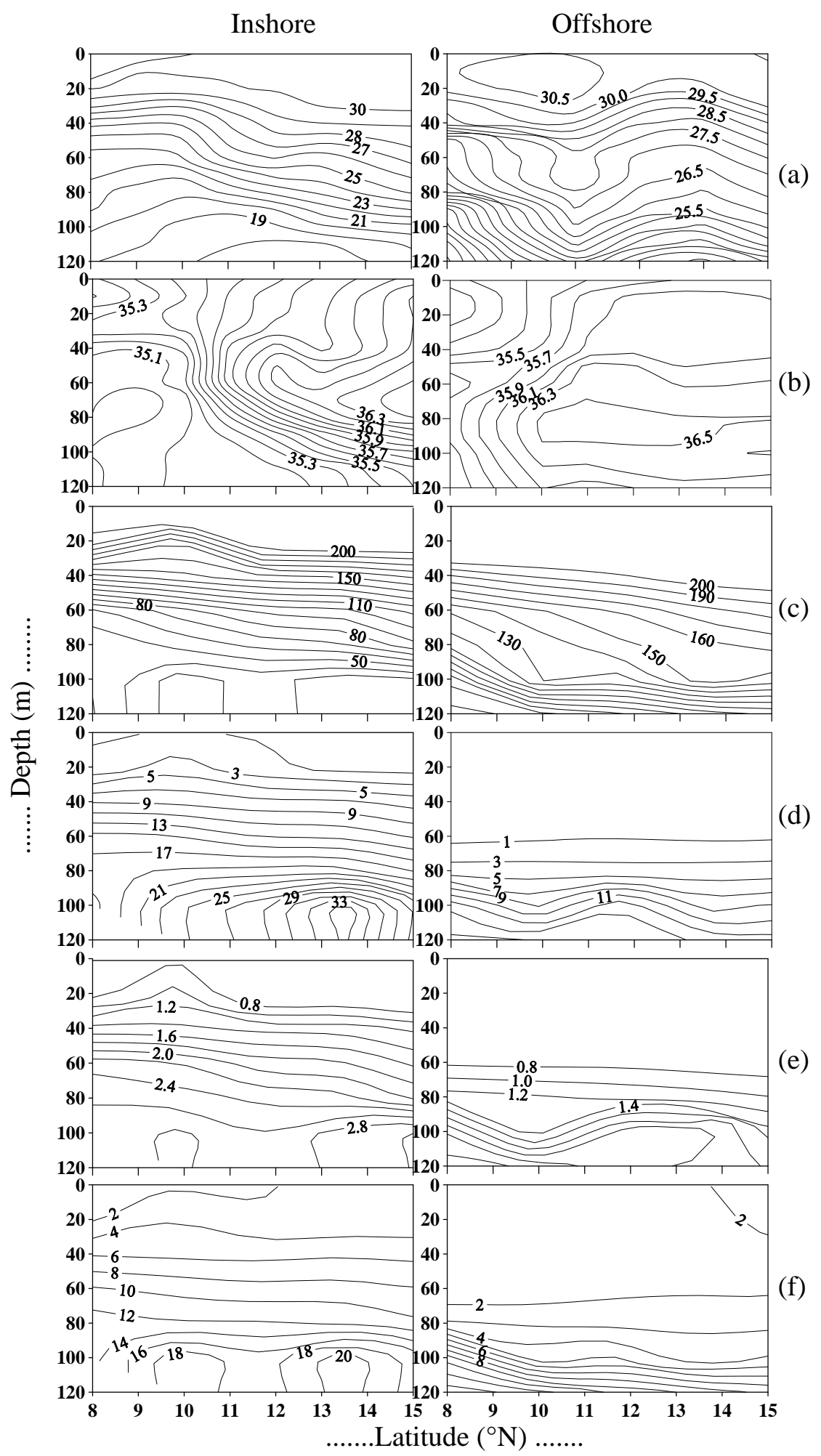

Figure 4 


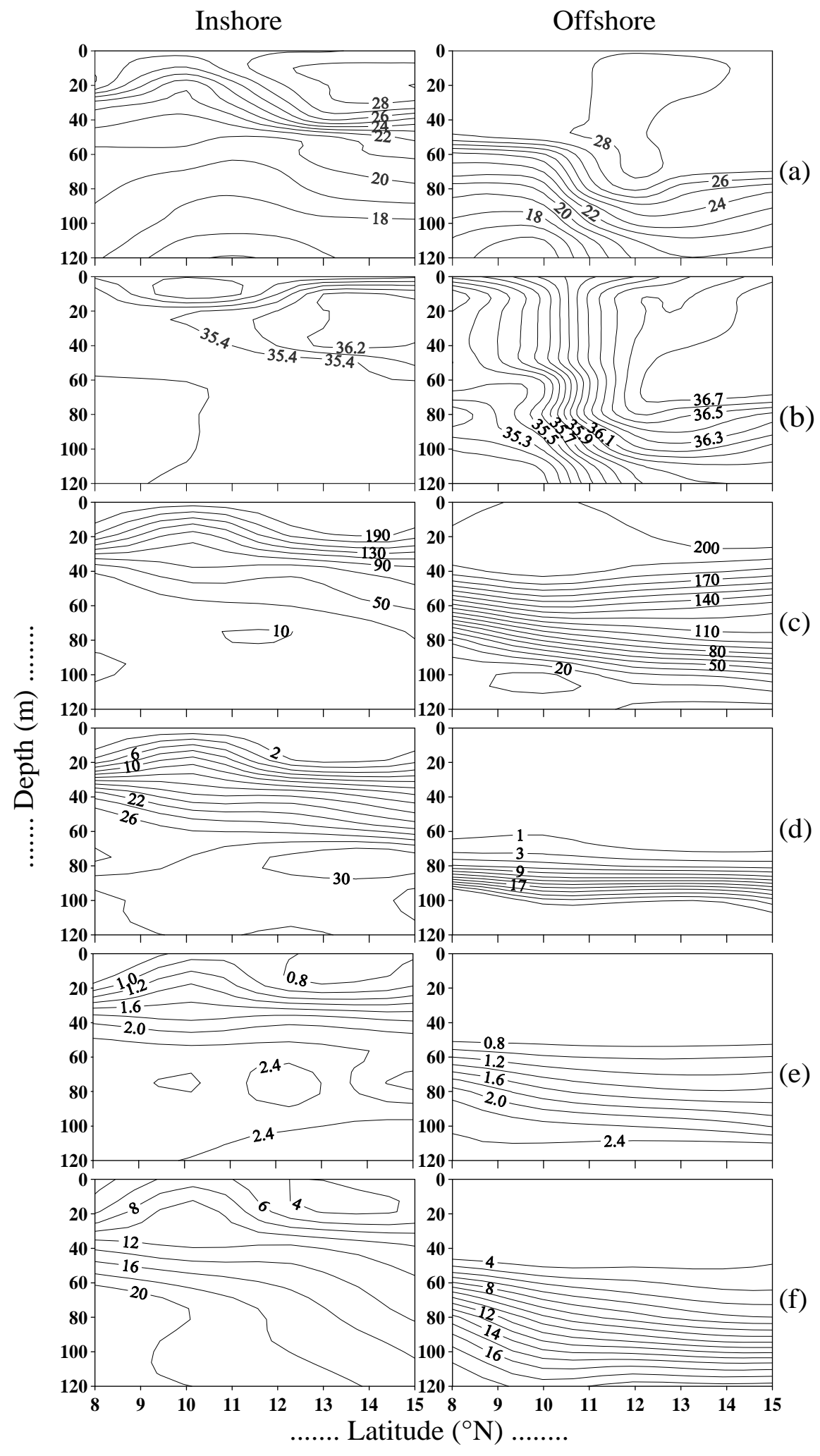

Figure 5 


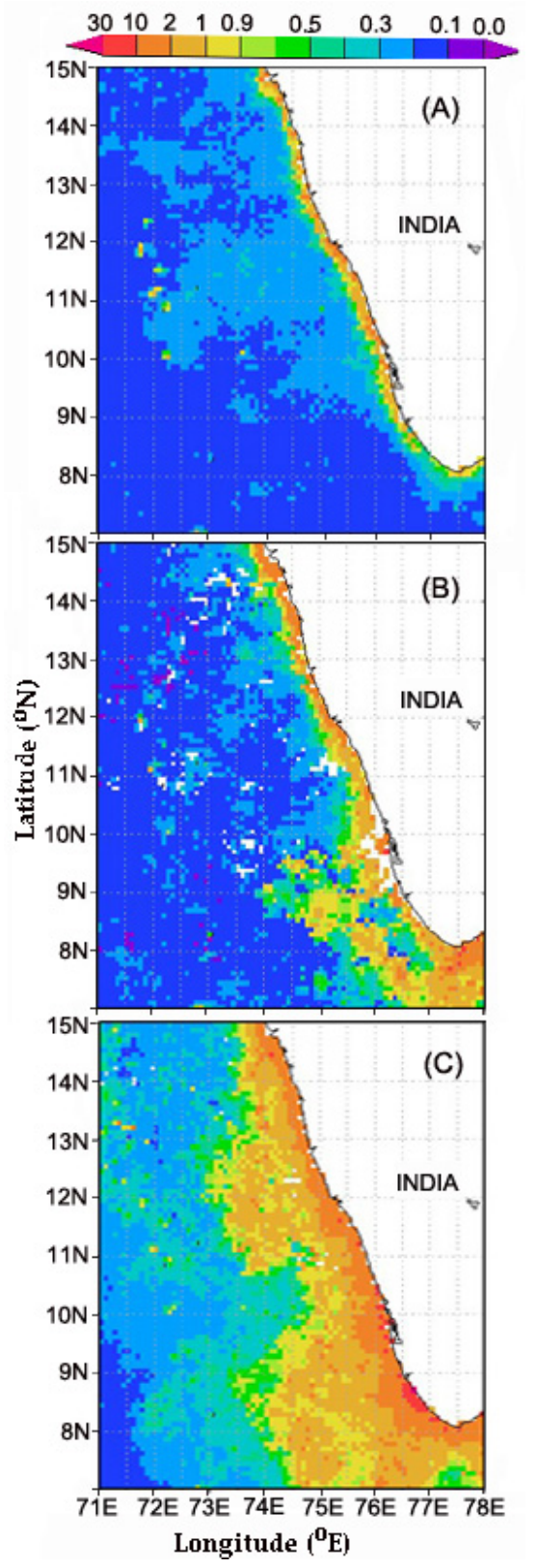

Figure 6 

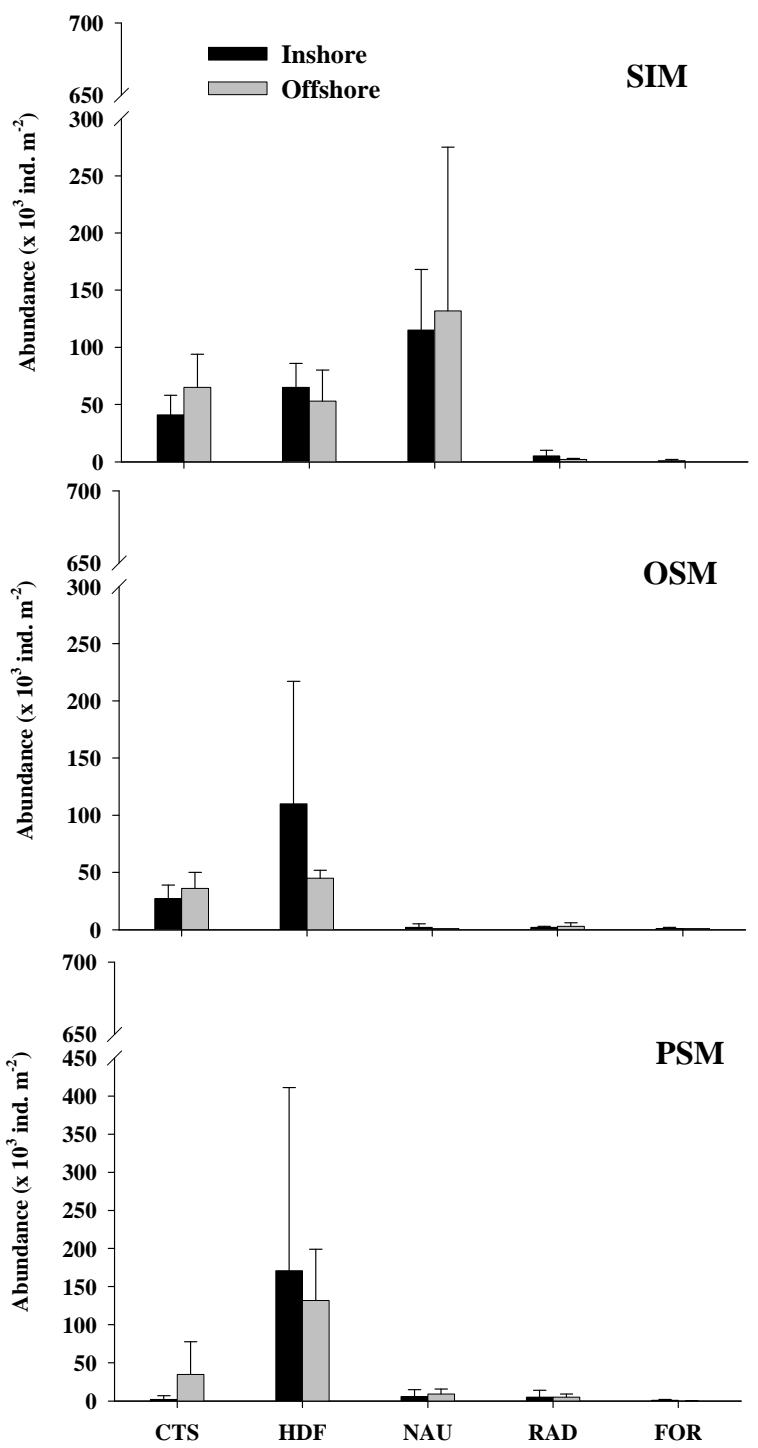

Figure 7 


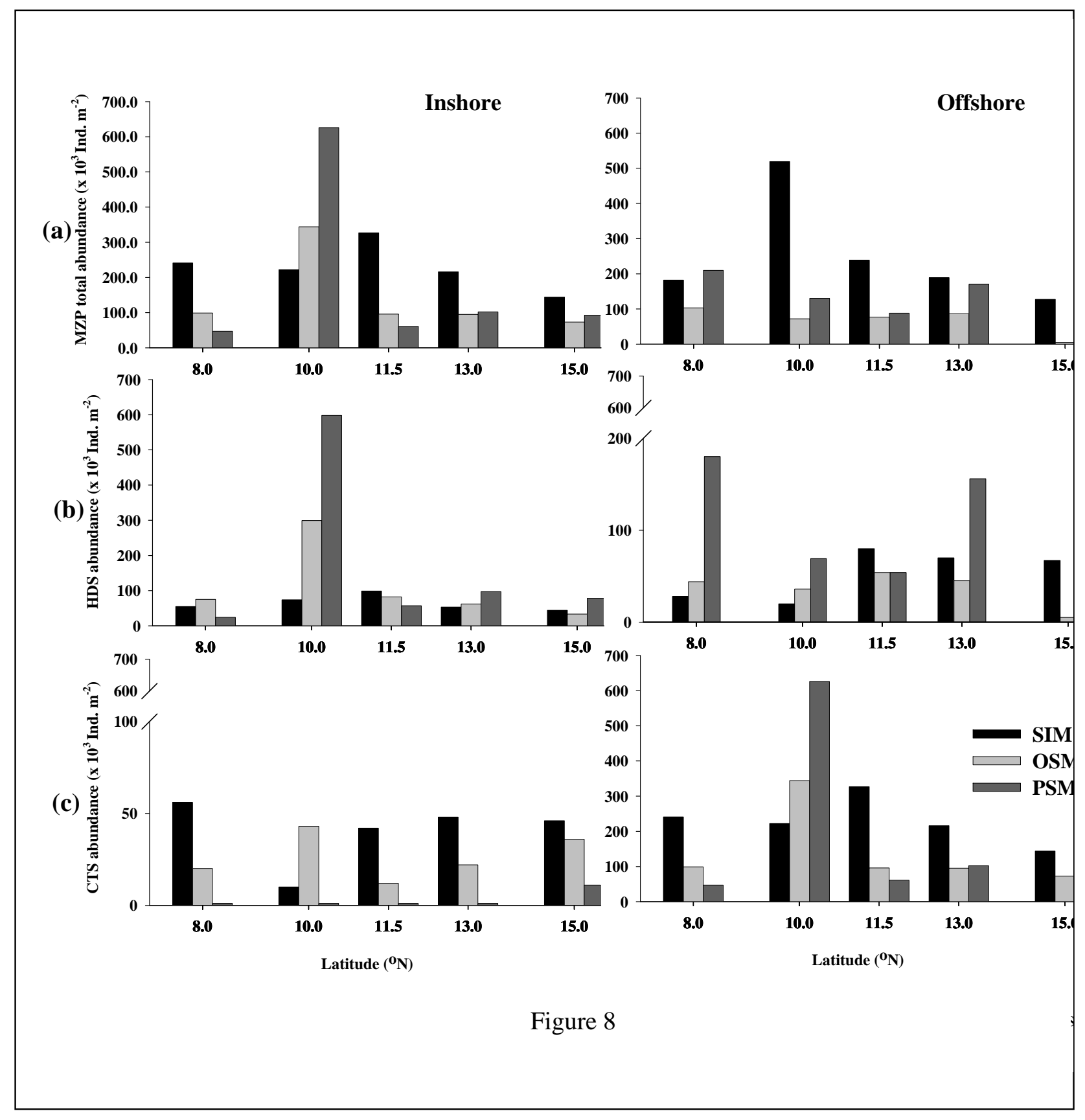



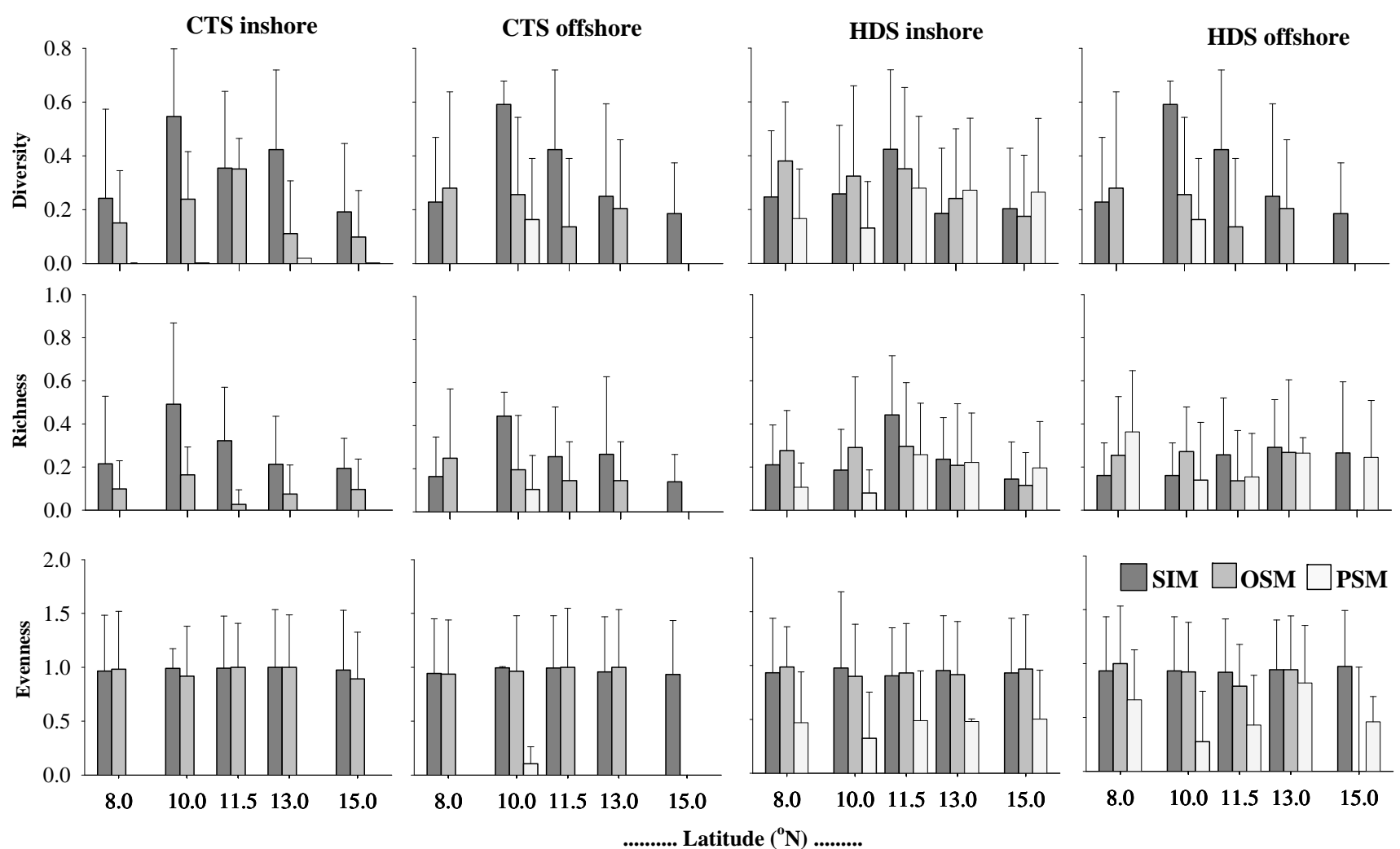

Figure 9 


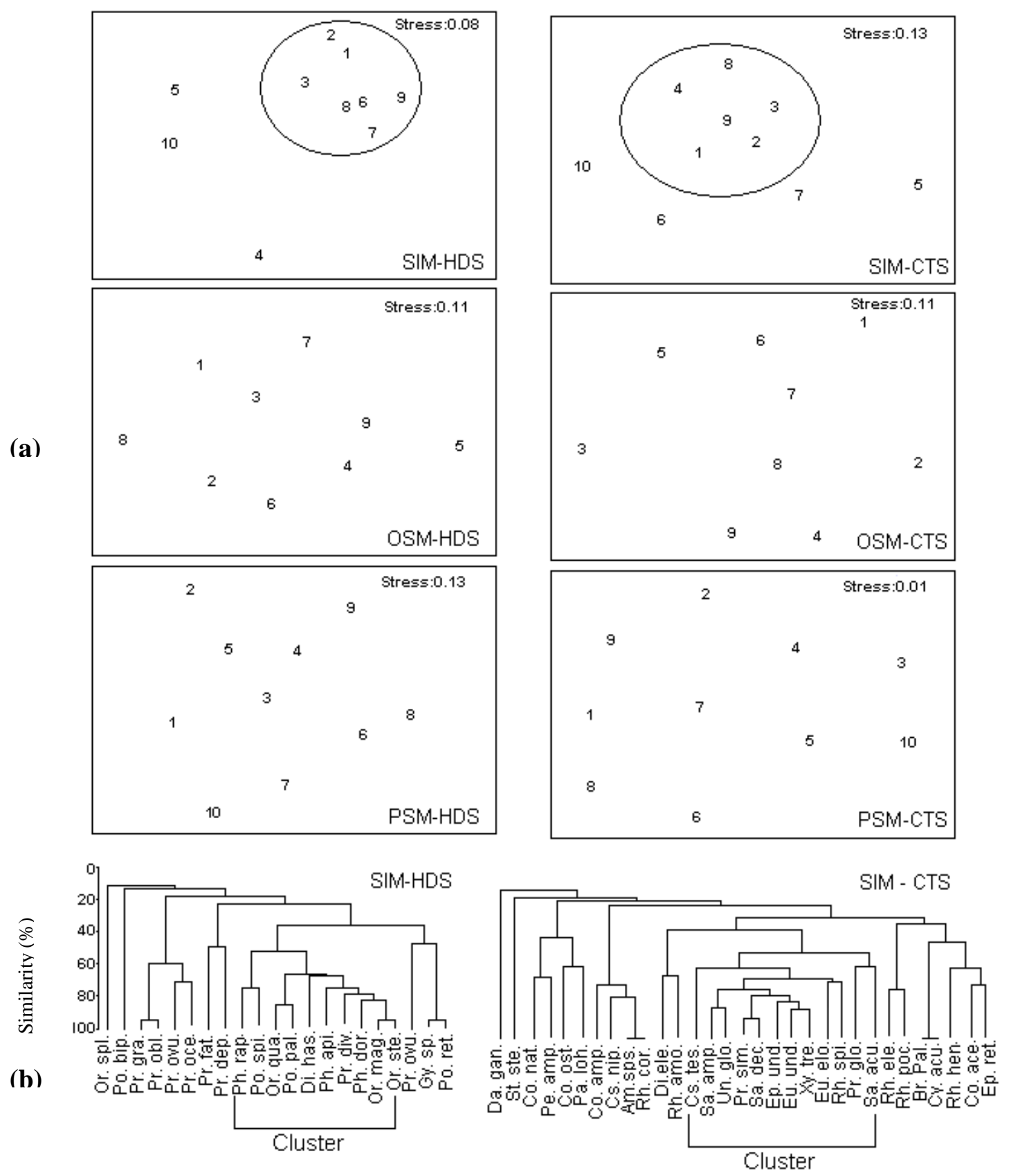

Figure 10 


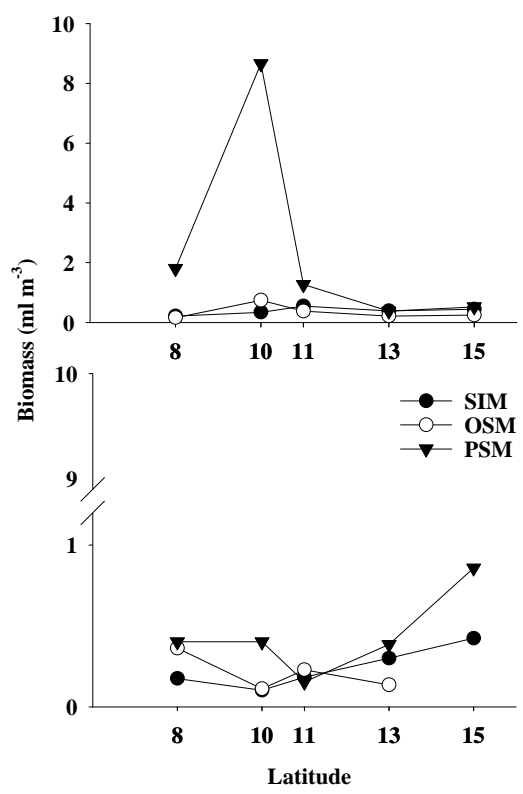

Figure 11 


\section{Figure captions}

Figure 1 - Station locations

Figure 2 - Horizontal distribution of (a) temperature (b) salinity (c) mixed layer depth

Figure 3 - Vertical distribution of (a) temperature (b) salinity (c) dissolved oxygen (d) nitrate (e) phosphate and (f) silicate during the spring intermonsoon

Figure 4 - Vertical distribution of (a) temperature (b) salinity (c) dissolved oxygen (d) nitrate (e) phosphate and (f) silicate during onset of summer monsoon

Figure 5 - Vertical distribution of (a) temperature (b) salinity (c) dissolved oxygen (d) nitrate (e) phosphate and (f) silicate during peak summer monsoon

Figure 6 - SeaWiFs images of chlorophyll $a$ during the (a) spring intermonsoon (b) onset of summer monsoon and (c) peak summer monsoon

Figure 7 - The seasonal relative abundance of major groups of MZP (CTS - ciliates, HDF Heterotrophic dinoflagellates, NAU- Nauplii, RAD - Radiolarians, FOR - Foraminifers)

Figure 8 - the abundance of (a) total microzooplankton (b) heterotrophic dinoflagellates (HDF) and (c) ciliates (CTS)

Figure 9 - Community structure indices of ciliates and heterotrophic dinoflagellates during the spring intermonsoon, onset of summer monsoon and peak summer monsoon

Figure 10 - Results of (a) MDS analysis and (b) hierarchical clustering

(Heterotrophic dinoflagellates: Di. has.- Dinophysis hastata ; Gy. Sp. - Gyrodinium sp. ; Or. mag. Ornithocercus magnificus ; Or. qua. - Ornithocercus quadratus ; Or. spl.- Ornithocercus splendidus; Or. ste. - Ornithocercus steinii; Ph. api. - Phalacroma apicatum; Ph. dor. - Phalacroma doryphorum; Ph. rap. - Phalacroma rapa; Po. bip. - Podolampus bipes; Po. pal. - Podolampus palmipes; Po. spi. Podolampus spinifera; Po. ret. - Podolampus reticulate; Pr. div. - Protoperidinium divergens; Pr. dep. Protoperidinium depressum; Pr. fat. - Protoperidinium fatulipes; Pr. gra. - Protoperidinium grandae; Pr. obl. - Protoperidinium oblongum; Pr. oce. - Protoperidinium oceanicum; Pr. ovu. - Protoperidinium ovum; Pr. pel. - Protoperidinium pellucidum. Ciliates: Am. spe - Amphorides species; Br. palBrandtiella pallida; Co. ace - Codonella acera; Co. amp - Codonella amphorella; Co. nat - Codonella nationalis; Co. nip - Codonellopsis nipponica; Co.ost - Codonellopsis ostenfeldii; Co. tes. Codonellopsis tesselata; Cy. acu - Cytarroyclis acutiformes; Da. gan. - Dadayiella ganymedes; Di. ele Dictyocysta elegans; Ep. ret. - Epipocyclis reticulate; Ep. und - Epipocyclis undella; Eu. elo Eutintinnus elongates; Eu. und. - Eutintinnus lusus undae; P. loh. - Parundella lohmani; Pe. amp. Petalotricha ampulla; Pr. sim. - Protorhabdonella simplex; Pr. glo - Proplectella globosa; Rh. amo. Rhabdonella amor; Rh. cor. - Rhabdonella cornucopia; Rh. ele. - Rhabdonella elegans; Rh. hen. Rhabdonella henseni; Rh. spi - Rhabdonella spiralis; Rhabdonella poculum; Sa. amp. - Salpingacantha ampla; Sa. acu. - Salpingella acuminate; Sa. dec. - Salpingella decurtata; St. ste. - Steenstrupiella steenstrupii; Un. glo. - Undella globosa; Xy.tre. - Xystonella trefortii) 
Figure 11- Mesozooplankton biomass in the (a) inshore and (b) offshore regions

\begin{tabular}{|c|c|c|c|c|}
\hline \multirow{3}{*}{$\begin{array}{l}\text { Latitude } \\
\qquad\left({ }^{\circ} \mathrm{N}\right)\end{array}$} & \multicolumn{4}{|l|}{ SIM } \\
\hline & \multicolumn{2}{|l|}{ Inshore } & \multicolumn{2}{|l|}{ Offshore } \\
\hline & $\begin{array}{c}\text { Chl } a \\
\mathrm{mg} \mathrm{m}^{-2}\end{array}$ & $\begin{array}{c}\mathrm{PP} \\
\mathrm{mg} \mathrm{C} \mathrm{m}^{-2} \mathrm{~d}^{-1}\end{array}$ & $\begin{array}{c}\text { Chl } a \\
\mathrm{mg} \mathrm{m}^{-2}\end{array}$ & $\begin{array}{c}\mathrm{PP} \\
\mathrm{mg} \mathrm{C} \mathrm{m}^{-2} \mathrm{~d}^{-1}\end{array}$ \\
\hline 8 & $\begin{array}{c}5 \\
(0.1) \\
\end{array}$ & $\begin{array}{c}74 \\
(3.3) \\
\end{array}$ & $\begin{array}{c}10 \\
(0.1)\end{array}$ & $\begin{array}{r}169 \\
(4.6) \\
\end{array}$ \\
\hline 10 & $\begin{array}{c}10 \\
(0.5)\end{array}$ & $\begin{array}{c}71 \\
(5.1)\end{array}$ & $\begin{array}{c}15 \\
(0.1)\end{array}$ & $\begin{array}{c}153 \\
(2.0)\end{array}$ \\
\hline 11.5 & $\begin{array}{c}15 \\
(0.3)\end{array}$ & $\begin{array}{c}238 \\
(2.2)\end{array}$ & $\begin{array}{c}22 \\
(0.1)\end{array}$ & $\begin{array}{c}117 \\
(4.0)\end{array}$ \\
\hline 13 & $\begin{array}{c}25 \\
(0.1)\end{array}$ & $\begin{array}{l}170 \\
(6.7)\end{array}$ & $\begin{array}{c}44 \\
(0.3)\end{array}$ & $\begin{array}{c}71 \\
(0.6)\end{array}$ \\
\hline 15 & $\begin{array}{c}20 \\
(0.1)\end{array}$ & $\begin{array}{l}267 \\
(6.4) \\
\end{array}$ & $\begin{array}{c}29 \\
(0.1) \\
\end{array}$ & $\begin{array}{l}127 \\
(3.2)\end{array}$ \\
\hline & OSM & & & \\
\hline 8 & $\begin{array}{c}23 \\
(0.3)\end{array}$ & $\begin{array}{c}360 \\
(11.7)\end{array}$ & $\begin{array}{c}25 \\
(0.1)\end{array}$ & $\begin{array}{c}190 \\
(2.0)\end{array}$ \\
\hline 10 & $\begin{array}{c}33 \\
(0.4)\end{array}$ & $\begin{array}{c}452 \\
(13.4)\end{array}$ & $\begin{array}{c}16 \\
(0.1)\end{array}$ & $\begin{array}{c}143 \\
(1.9)\end{array}$ \\
\hline 11.5 & $\begin{array}{c}16 \\
(0.2)\end{array}$ & $\begin{array}{c}229 \\
(4.4)\end{array}$ & $\begin{array}{c}15 \\
(0.2)\end{array}$ & $\begin{array}{c}218 \\
(3.1)\end{array}$ \\
\hline 13 & $\begin{array}{c}13 \\
(0.3)\end{array}$ & $\begin{array}{c}205 \\
(9.9)\end{array}$ & $\begin{array}{c}21 \\
(0.2)\end{array}$ & $\begin{array}{c}242 \\
(5.5)\end{array}$ \\
\hline 15 & $\begin{array}{c}21 \\
(0.2)\end{array}$ & $\begin{array}{c}258 \\
(5.0)\end{array}$ & - & - \\
\hline & PSM & & & \\
\hline 8 & $\begin{array}{c}56 \\
(1.2) \\
\end{array}$ & $\begin{array}{c}607 \\
(38.6) \\
\end{array}$ & $\begin{array}{c}16 \\
(0.2)\end{array}$ & $\begin{array}{c}123 \\
(2.1) \\
\end{array}$ \\
\hline 10 & $\begin{array}{c}46 \\
(2.0) \\
\end{array}$ & $\begin{array}{c}736 \\
(122) \\
\end{array}$ & $\begin{array}{c}29 \\
(0.5) \\
\end{array}$ & $\begin{array}{c}821 \\
(15.5)\end{array}$ \\
\hline 11.5 & $\begin{array}{c}69 \\
(1.5) \\
\end{array}$ & $\begin{array}{c}1314 \\
(35.4) \\
\end{array}$ & $\begin{array}{c}9 \\
(0.2) \\
\end{array}$ & $\begin{array}{c}84 \\
(3.8) \\
\end{array}$ \\
\hline 13 & $\begin{array}{c}16 \\
(0.2)\end{array}$ & $\begin{array}{c}242 \\
(6)\end{array}$ & $\begin{array}{c}14 \\
(0.2)\end{array}$ & $\begin{array}{c}271 \\
(4.6)\end{array}$ \\
\hline 15 & $\begin{array}{c}19 \\
(0.7)\end{array}$ & $\begin{array}{c}167 \\
(17.1)\end{array}$ & $\begin{array}{c}19 \\
(0.7)\end{array}$ & $\begin{array}{c}167 \\
(17.1)\end{array}$ \\
\hline
\end{tabular}

Table 1 - Seasonal variations of surface $\left(\mathrm{mg} \mathrm{m}^{-3}\right)$, integrated chlorophyll $a\left(\mathrm{mg} \mathrm{m}^{-2}\right)$, surface primary production (mgC $\mathrm{m}^{-3} \mathrm{~d}^{-1}$ ) and integrated primary production (mgC $\mathrm{m}^{-2} \mathrm{~d}^{-1}$ ) during the spring intermonsoon (SIM), onset of summer monsoon (OSM) and peak summer monsoon (PSM) periods. Values in brackets represent the surface. 
SIM

OSM

PSM

\begin{tabular}{|c|c|c|c|c|c|c|}
\hline Species Name & Inshore & Offshore & Inhsore & Offshore & Inhsore & Offshore \\
\hline Gyrodinium sp. & + & - & - & + & + & - \\
\hline Dinophysis hastata & + & - & + & + & + & - \\
\hline Ornithocercus magnificus & + & + & + & + & + & + \\
\hline O. quadratus & + & + & - & + & - & - \\
\hline O. splendidus & + & - & + & + & - & - \\
\hline O. steinii & + & + & + & + & + & + \\
\hline O. thumii & - & - & - & + & + & + \\
\hline Phalacroma apicatum & + & + & + & + & + & - \\
\hline P. doryphorum & + & + & + & + & + & + \\
\hline P. rapa & + & + & + & + & - & + \\
\hline Podolampus bipes & + & - & + & - & - & - \\
\hline P. palmipes & + & + & + & - & + & + \\
\hline P. spinifera & + & + & + & + & & + \\
\hline P. reticulata & + & + & + & + & + & + \\
\hline Protoperidinium divergens & + & + & + & + & + & + \\
\hline P. depressum & - & + & - & - & + & - \\
\hline P. elegans & - & - & + & - & + & + \\
\hline P. fatulipes & + & + & + & & + & + \\
\hline P. globulus & - & - & - & - & + & - \\
\hline P. grandae & + & - & - & - & + & + \\
\hline P. leonis & + & - & - & - & + & - \\
\hline P. nipponicum & - & - & + & + & + & + \\
\hline P. oblongum & + & + & - & - & - & - \\
\hline P. oceanicum & + & + & + & + & + & + \\
\hline P. ovum & - & + & + & + & + & + \\
\hline P. pellucidum & + & - & - & - & - & - \\
\hline
\end{tabular}

Table 2 - Species composition of heterotrophic dinoflagellates during the (a) spring intermonsoon (SIM), onset of summer monsoon (OSM) and peak summer monsoon (PSM). + present and - absent. 


\begin{tabular}{|c|c|c|c|c|c|c|}
\hline \multirow[b]{2}{*}{ Species Name } & \multicolumn{2}{|c|}{ SIM } & \multicolumn{2}{|c|}{ OSM } & \multicolumn{2}{|c|}{ PSM } \\
\hline & Inshore & Offshore & Inshore & Offshore & Inshore & Offshore \\
\hline Amphorides sp. & - & + & - & - & - & - \\
\hline Amphorella quadrilineata & - & - & + & - & - & - \\
\hline Brandtiella pallida & - & + & - & + & - & - \\
\hline Codonella acera & + & + & + & + & + & + \\
\hline C. amphorella & - & + & + & + & - & - \\
\hline C.nationalis & + & - & + & + & - & - \\
\hline Codonellopsis nipponica & + & + & - & + & - & - \\
\hline C. ostenfeldii & + & + & - & - & - & - \\
\hline C. tesselata & + & + & + & + & - & + \\
\hline C. ecuadata & - & - & + & + & - & - \\
\hline Coxliella sp. & - & - & + & - & - & - \\
\hline Cymatocyclis vanhoeffeni & - & - & + & - & - & - \\
\hline Cytarroyclis acutiformes & - & + & - & - & - & - \\
\hline Dadayiella ganymedes & - & - & - & - & - & - \\
\hline Dictyocysta elegans & + & + & - & - & - & - \\
\hline D. grandis & - & - & + & + & - & - \\
\hline D. lepida & - & - & - & - & - & + \\
\hline Epipocyclis reticulata & + & + & + & - & - & - \\
\hline E. undella & + & + & + & + & - & - \\
\hline Eutintinnus elongatus & + & + & & + & - & - \\
\hline E. lusus undae & + & + & + & + & - & - \\
\hline Favella brevis & - & - & - & - & - & + \\
\hline Helicostomella subulata & - & - & + & - & - & - \\
\hline Lohmaniella spiralis & - & - & - & + & - & - \\
\hline Parundella lohmani & + & + & + & + & - & - \\
\hline Petalotricha ampulla & + & - & + & + & - & - \\
\hline Protorhabdonella simplex & + & + & + & - & - & - \\
\hline Proplectella globosa & + & + & - & + & - & - \\
\hline Rhabdonella amor & + & + & + & + & - & - \\
\hline R. cornucopia & - & + & - & - & - & - \\
\hline R. elegans & + & + & - & - & - & - \\
\hline R. henseni & + & - & - & + & - & - \\
\hline R. spiralis & + & + & + & + & - & - \\
\hline R. poculum & + & + & + & + & - & - \\
\hline Salpingacantha ampla & + & + & + & - & - & - \\
\hline Salpingella acuminata & + & + & - & - & - & - \\
\hline S. decurtata & + & + & - & - & - & - \\
\hline Steenstrupiella steenstrupii & + & - & + & - & - & - \\
\hline Tintinnidum incertum & - & - & - & - & - & + \\
\hline Undella hyalina & - & - & - & + & + & - \\
\hline U. globosa & + & + & + & + & - & - \\
\hline Xystonella trefortii & + & + & + & + & - & - \\
\hline
\end{tabular}

Table 3 - Species composition of ciliates during the (a) spring intermonsoon (SIM), onset of summer monsoon (OSM) and peak summer monsoon (PSM). + present and - absent 


\begin{tabular}{lcccccc}
\hline $\begin{array}{l}\text { Zooplankton } \\
\text { Groups }\end{array}$ & \multicolumn{2}{c}{ SIM } & \multicolumn{2}{c}{ OSM } & PSM \\
\cline { 2 - 7 } & Inshore & Offshore & Inshore & Offshore & Inshore & Offshore \\
\hline Siphonophores & $0.91 \pm 0.81$ & $1.84 \pm 2.05$ & $0.72 \pm 0.67$ & $1.57 \pm 0.40$ & $187.85 \pm 414.5$ & $2.57 \pm 2.80$ \\
\hline Pteropods & $1.03 \pm 1.18$ & $0.49 \pm 0.87$ & $39.26 \pm 54.80$ & $0.35 \pm 0.28$ & $1.04 \pm 1.2$ & $1.07 \pm 1.54$ \\
\hline Ostracods & $11.60 \pm 10.14$ & $3.22 \pm 2$ & $40.86 \pm 51.76$ & $0.76 \pm 1.10$ & $124.37 \pm 186$ & $58.93 \pm 86.55$ \\
\hline Copepods & $229.7 \pm 118.8$ & $197.7 \pm 117.2$ & $784.64 \pm 656.78$ & $224 \pm 77.51$ & $1354.62 \pm 1776.3$ & $251.37 \pm 67.04$ \\
\hline Euphausids & $0.08 \pm 0.12$ & $0.26 \pm 0.33$ & $2.14 \pm 3.13$ & $0.70 \pm 0.67$ & $24.12 \pm 28.79$ & $2.23 \pm 1.62$ \\
\hline Decapods & $3.49 \pm 2.45$ & $0.75 \pm 0.57$ & $7.82 \pm 4.37$ & $1.86 \pm 1.25$ & $24.60 \pm 37.82$ & $5.59 \pm 5.88$ \\
\hline Chaetognaths & $29.53 \pm 9.61$ & $13.44 \pm 2.91$ & $20.27 \pm 20.87$ & $15.01 \pm 4.71$ & $40.82 \pm 44.38$ & $26.82 \pm 19.94$ \\
\hline Copelates & $8.48 \pm 14.5$ & $3.12 \pm 4.01$ & $24.46 \pm 39.29$ & $2.08 \pm 2.27$ & $7.33 \pm 8.55$ & $0.36 \pm 0.34$ \\
\hline Fish larvae & $0.57 \pm 0.45$ & $0.05 \pm 0.08$ & $1.09 \pm 1.15$ & $0.28 \pm 0.29$ & $1.31 \pm 2.42$ & $0.15 \pm 0.13$ \\
\hline
\end{tabular}

Table 4- Seasonal abundance (No. $\mathrm{m}^{-3}$ ) of major zooplankton groups 